\title{
The Neuropeptide System and Colorectal Cancer Liver Metastases: Mechanisms and Management
}

\author{
Aldona Kasprzak ${ }^{1, *(1)}$ and Agnieszka Adamek ${ }^{2}$ (-) \\ 1 Department of Histology and Embryology, University of Medical Sciences, Swiecicki Street 6, \\ 60-781 Poznań, Poland \\ 2 Department of Infectious Diseases, Hepatology and Acquired Immunodeficiencies, University of Medical \\ Sciences, Szwajcarska Street 3, 61-285 Poznań, Poland; agnieszkaadamek@ump.edu.pl \\ * Correspondence: akasprza@ump.edu.pl; Tel.: +48-61-8546441; Fax: +48-61-8546440
}

Received: 15 April 2020; Accepted: 11 May 2020; Published: 15 May 2020

\begin{abstract}
Colorectal cancer (CRC), classified as the third most prevalent cancer worldwide, remains to be a clinical and research challenge. It is estimated that $\sim 50 \%$ of CRC patients die from distant metastases, with treatment of this complication still posing significant difficulties. While liver metastasis (LM) cascade is known in the literature, its mechanisms are still unclear and remain studied in different research models. A connection is suggested between nervous system dysfunctions and a range of Neurotransmitters (Nts) (including Neuropeptides, NPs), Neurotrophins (Ntt) and their receptors (Rs) in CRC liver metastasis development. Studies on the role of NP/NP-Rs in the progression and metastasis of CRC, show the complexity of brain-tumor interactions, caused by their different forms of release to the extracellular environment (endocrine, autocrine, paracrine and neurocrine). Many stages of LM are connected to the activity of pro-inflammatory, e.g., Corticotropin-releasing Hormone Receptor 1 (CRHR1), Neuropeptide Y (NPY) and Neurotensin (NT), anti-inflammatory, e.g., Calcitonin Gene-related Peptide (CGRP), CRHR2 and Vasoactive Intestinal Polypeptide (VIP) or dual role neuropeptides, e.g., Substance P (SP). The regulation of the local immunological profile (e.g., CRH/CRHRs), dysfunctions of enteroprotective role of NPs on epithelial cells (e.g., NT/NT-R), as well as structural-functional changes in enteric nervous system innervation of the tumor are also important. More research is needed to understand the exact mechanisms of communication between the neurons and tumor cells. The knowledge on the mechanisms regulating tumor growth and different stages of metastasis, as well as effects of the action of a numerous group of Nts/NPs/Ntt as growth factors, have implications for future therapeutic strategies. To obtain the best treatment outcomes, it is important to use signaling pathways common for many NPs, as well to develop a range of broad-spectrum antagonists. This review aims to summarize the current knowledge on the importance of neuroactive molecules in the promotion of the invasion-metastasis cascade in CRC, as well as the improvements of clinical management of CRC liver metastasis.
\end{abstract}

Keywords: colorectal cancer; liver metastasis; neuropeptides; nervous system-tumor interactions

\section{Introduction}

Colorectal cancer (CRC), classified as the third most prevalent cancer worldwide, after lung and breast/prostate cancer, is also the second leading cause of cancer-associated death [1,2]. Among all the cancers diagnosed in Europe, CRC is the second most widespread (after female breast cancer), also being the second most common cause of cancer-associated death (after lung cancer) [3]. Around 25\% of CRC patients exhibit synchronous liver metastases (LM), with around 60\% developing metachronous LM during the disease [4-6]. The liver is the most common metastasis location in CRC [7-10] and, most importantly, often the only metastasis-affected site [11]. LM in CRC, as a usually asymptomatic 
condition, is often recognized in late stages, shortening the survival time of patients by 5 to 20 months with no treatment $[9,11,12]$. The prevalence of LM is higher in stage IV of CRC cases than in curatively resected cases, being comparable to autopsy detected CRC ( 85\%) [13]. CRC remains to be a clinical and research challenge, as it is estimated that $\sim 50 \%$ of CRC patients die from distant metastases, and treatment of this complication still poses significant difficulties [14-16].

While LM cascade is known in the literature $[11,17,18]$, its mechanisms are still unclear and are studied in different research models [12,17-22]. LM in CRC is most commonly associated with anatomical location of organs and portal circulation (mechanical, hemodynamic or anatomic hypotheses) $[9,13]$, but also with the location of the primary tumor (more commonly colon than rectum) and histological CRC subtype (most often adenocarcinoma) [7,23]. Liver metastases are also more often associated with commonly recognized CRC risk factors, such as sex (more prevalent in men), age (more common in women over 70 years of age, as compared to younger) [7], diabetes [24], high levels of low-density cholesterol (LDL) and LDL receptor (LDLR) [25] or alcohol consumption [26]. The role of obesity in CRC LM is still an open matter [27].

A strong connection is suggested between brain-gut axis dysfunctions, the expression of a range of Neurotransmitters (Nts) (including Neuropeptides, NPs), as well as Nerve Growth Factor (NGF) family of proteins called Neurotrophins (Ntt) and the progression of CRC (including distant metastases) [17,18,28-30].

The word "neuropeptide" was first used by David de Wied (1971), defining it as a peptide hormone devoid of the hormone of origin activity but able to exert effects on its own [31,32]. Other authors refer to NPs as small protein substances produced and released by neurons through the regulated secretory route, that lack endocrine activity in the brain but act on neural substrates to exert an effect on the target cell [33-35]. The concept of NPs was gradually redefined, recognizing that the name could also be used for regular peptide hormones, e.g., adrenocorticotropic hormone (ACTH), as they were also proven to be produced by neurons [31].

Neuropeptides are classified as complementary to classic Nts, sometimes even considered as their subtype, regardless of being produced by the cells of central and peripheral nervous system (neurons, glial cells), or non-neuronal cells (e.g., enteroendocrine cells, EECs), if they share the same genetic information, identical processes of synthesis and transport, as well as binding to similar families of receptors, allowing them to act on neural processes [34-37]. NPs are secreted to the synaptic space (neurotransmission), to tissue fluids (paracrine action) or blood (endocrine function) [35,36,38]. NP spectrum of activity is very wide, from the mentioned Nts to growth factors and key inflammatory mediators [39,40]. Recent studies indicate that NP signaling is evolutionarily conserved [41].

NPs are produced as biologically active precursor products of 100-200 amino acids (aa) and then trimmed to shorter peptides (3-100 aa), stored in neurons, in electron dense-core vesicles, together with one or two smaller Nts [36,39]. Currently, the human genome is described to contain around 90 genes coding NP precursors. There are $\sim 100$ peptides that can be produced and secreted by various neuron populations in mammalian brain [42].

NP action occurs through their specific, mostly G protein-coupled receptors (GPCRs), that are usually characterized by a seven-transmembrane region [33,34,36,38-40,43]. Understanding the structure of NP receptors (NP-Rs) opened the opportunity to design drugs which could be used in the treatment of diseases, such as inflammatory bowel diseases (IBD), irritable bowel syndrome (IBS), as well as epithelial-derived cancers, e.g., neuroendocrine tumors (NETs) or CRC [35,36,39,40,44-46].

Discovery of several NPs in the large intestine, as well as the elucidation of their roles, has a significant clinical application. Some of them (e.g., progastrin) were even considered as potential tissue CRC LM biomarkers [47]. Others (e.g., Glucagon-like Peptide (GLP) and peptide YY (PYY)) are used in immunophenotypic classification and prognosis of rectal NETs. It was proven that non-L-cell immunophenotype and larger tumor size $(>1 \mathrm{~cm})$ were associated with distant metastases [48]. Recent papers indicate that plasma concentration of neurotensin (NT), can, with high sensitivity and specificity, differentiate colon pathology (including CRC) from normal colonic epithelium [49]. 
The aim of this study was to summarize the current knowledge on the key roles of neuroactive molecules and their receptors in the human brain-gut axis, which have a proven or implied role in the mechanisms of CRC LM. CRC was chosen for the analysis, as in this cancer, LM is the most common cause of death, while the involvement of nerve dysfunctions accompanying $\mathrm{CRC}$, as well as the role of the complex NP system in LM, still seems to be relatively poorly described.

\section{Large Intestine Innervation as a Physiological NP Source}

Innervation of the large intestine is a combination of central nervous system (CNS) elements (extrinsic innervation) with the enteric nervous system (ENS) (intrinsic innervation) [50-52]. Extrinsic innervation includes the autonomic nervous system (ANS) with sympathetic (SNS) and parasympathetic (PSN) branches, which originates directly in the CNS. The intrinsic innervation is composed of nerve cell clusters (enteric ganglia, submucosal (Meissner's) and myenteric (Auerbach's) plexuses (MPs)), and nerve fibers in the gastrointestinal tract (GIT) wall [50,52]. ENS nerve fibers innervate intestinal muscular layer, blood vessels and EECs, while the role of MPs in the large intestine is mostly the control of intestinal motility and descending phase of peristaltic reflex through the production of NPs, e.g., Gastrin-Releasing Peptide (GRP) [53,54], while Calcitonin-Gene-Related Peptide (CGRP) plays a cytoprotective role in intestinal mucosa cells [55]. In contrast, somatostatin (SM) inhibits intestinal motility and secretory activity [56]. The neuronal regulation via innervation of the crypts also concerns the differentiation and renewal of intestinal epithelial cells [51]. The production of NT Receptor 1 (NTSR1) and NTSR3 (but not NTSR2) was proven in sigmoid colon circular muscle and taenia coli. Functionally, this NP is responsible for direct (muscle) and indirect (neuronal/non-neuronal mechanism) smooth muscle contraction from ascending and sigmoid regions of the human colon, while the descending colon shows higher dependence on tachykinins (TAC), prostaglandins (PGEs), histamine and nitric oxide [57,58].

The main Nt of SNS in the proximal colon is norepinephrine (NE), acting through adrenergic GPCRs to control the vascular tone, enteric smooth muscle activity and inhibit the mucosal secretion $[51,52]$.

PSN is represented by vagus nerve, which regulates the motility of the proximal colon. The main $\mathrm{Nt}$ of PNS is acetylcholine (ACh) associated with Muscarinic Receptors (MRs), also known as Cholinergic/Acetylcholine Receptors (CHRM) and nicotinic receptors [51,52]. The epithelial cell proliferation and differentiation are stimulated directly through the cholinergic myenteric neurons, through the release of ACh and serotonin (5-HT). In turn, myenteric neurons are regulated by axonal reflexes from sensory afferent neurons, which produce Substance P (SP) and CGRP [51]. Nerve fibers from the SNS and PSN innervate the whole large intestinal wall, creating synapses with ENS, with only the SNS fibers reaching the intestinal mucosa [52].

The structural-functional connection between the GIT and the nervous system also occurs due to the EECs (neuroendocrine, APUD cells), which are also a source of Nts and NPs. While 12 types of EECs are currently described, three types are present in the large intestine: enterochromaffin (EC, Ecm) cells (most prevalent), L cells ( $14 \%$ of the EEC population in the rectum) and D cells ( $3-5 \%$ of the EEC population in all lower GIT) [59,60]. All of the NPs produced by EECs act through receptors on EECs, and other cells of the intestinal wall (e.g., smooth muscle and immune cells, enteric neurons) and nerve terminals. Some reports even suggest the presence of true synapses between neurons and EECs $[52,60,61]$. In the large intestine, 7 clear clusters of EECs can be differentiated, among which 4 clusters are EC/Ecm cells characterized by high expression of Tph1, encoding the Tryptophan 5-hydroxylase (TPH) enzyme for 5-HT synthesis [61]. Therefore, the major type of EECs in the large intestine are the EC/Ecm cells, producing 5-HT [60,61]. Further, two EECs clusters consist of L cells, rich in the Gcg, encoding GLP1, as well as seven clusters coding SM (D-cells). Among the L-cells, 4 sub-clusters can be distinguished, characterized by differential expression of Gcg, Pyy (PYY), NTs (NT), Insl5 (Insulin-like Peptide 5, ILP5), Cck (Cholecystokinin, CCK) and Sct (Secretin). Changes in NP expression intensity were reported, dependent on location, cellular maturity (crypt-surface) and the anatomical region of the intestine (proximal-distal axes) [58,61]. Distal colonic/rectal L-cells also exhibit 
differential expression of the type-1A angiotensin II (ANG II) receptor gene (Agtr1a), which causes a significant increase in plasma levels and in vivo production of GLP1, and PYY release in response to their stimulation with ANG II [61].

\section{Alterations in Large Intestine Innervation during CRC}

There is evidence of a direct link between the nervous system and cancer through synapses, non-synapse contacts, or humoral modulation, which contribute to two-way communication and influence cancer metastases. Similar to nerve structures, cancer cells produce Nts/NPs and their receptors [62,63]. In CRC patients, structural and functional changes of large intestine innervation can be observed. Interestingly, in the CRC LM, contrarily to the healthy liver, a lack of autonomic perivascular Protein Gene Product 9.5. (PGP9.5)- and Neuropeptide Y (NPY)-immunoreactive nerves can be observed [64].

\subsection{Morphological Changes in Innervation and Neuropeptide Panel in CRC}

Structural changes in CRC innervation mostly concern ENS, occurring most commonly in the form of gradual reduction, leading to the total destruction of the nerve structures [65-67]. Atrophy of submucosal and MPs within close proximity to the tumor occurs $[67,68]$. Among the NPs, a decrease in CGRP+ neurons and nerves was observed in both plexus types in the transitional zone between cancerous area and unchanged tissue. The decrease also concerned SP+ nerve fibers in all intramural plexuses [65] and NPY-ergic neurons, as well as the density of nerve fibers in both plexuses [66]. Interestingly, there were no significant quantitative differences in the numbers of $\mathrm{SP}+, \mathrm{SM}+$, Vasoactive Intestinal Polypeptide (VIP)-ergic and Pituitary Adenylate Cyclase-activating Peptide (PACAP)-ergic neurons, as well as $\mathrm{SM}+$ nerve fibers in cancer, compared with healthy regions $[65,66]$. Lower numbers of VIP-ergic and PACAP-ergic nerve fibers were observed in submucosal and MPs than in control sections [66]. In turn, an unchanged density of galanin (Gal)-positive nerve fibers was observed, while the percentage of Gal+ neurons was higher in CRC (46\%) than the healthy intestine (35\%) [68]. A reduction in the size of Gal+ MPs in the vicinity of the tumor was also reported, as compared with unchanged tissue [67]. Mean Gal content in tumor was lower $(9.38 \mathrm{ng} / \mathrm{g})$ than in the morphologically unaltered intestine (12.27 ng/g) [68]. Ultrastructural changes in CRC patients include an increase in the mass of extracellular matrix (ECM), occurrence of myelin-like structures, numerous apoptotic cells, as well as the presence of mast and plasma cells in MPs in the tumor surrounding area [69].

\subsection{The Perineural Invasion (PNI) in CRC}

There are ongoing studies on the involvement of perineural invasion (PNI) of cancer cells in the modulation of tumorigenesis [62,63,70]. PNI might be an underestimated mode of metastasis spread, acting in combination with lymphatic and vascular invasion [70-73], as well as on its own [70]. In CRC, $\sim 16-40 \%$ of the patients exhibited PNI characterized by neoplastic invasion of nerves, with altered molecular determinants of the process [70]. It is debated if nerve ablation can delay/inhibit the formation of tumors and/or reduce metastaticity [63].

The markers closely associated with PNI include Nts (e.g., ACh, NE and their receptors: AChR, NE-R), Ntt (NGF, Brain-Derived Neurotrophic Factor (BDNF), Glial Cell line-derived Neurotrophic Factor (GDNF) and their receptors: Neurotrophic Receptor Tropomyosin-related Kinase B (TrKB)), as well as typical NPs (e.g., SP, Gal, NPY/CGRP) [63,70]. PNI is a multistep process, during which a major role is played by the so-called perineural niche, together with numerous signaling molecules (including NPs/NP-Rs) [70]. There is a lack of detailed studies on the mechanisms of nerve-tumor interactions in PNI in CRC, as most of the research concerns different types of cancer (e.g., prostate and gastric cancers, pancreatic ductal adenocarcinoma) [63,70]. However, a prognostic role of PNI was proven in CRC. Defining PNI as a presence of cancer cells inside the nerve sheath, or at least $33 \%$ of the nerve periphery surrounded by cancer cells in CRC, shorter 5-year survival rates were observed compared with negative PNI. Additionally, positive correlations between PNI and lymph node 
metastases, tumor grade depth of invasion, clinical-stage, vessel invasion and tumor growth pattern were observed [74]. PNI was indicated as an independent bad prognostic factor in CRC [70,72,74], affecting both overall survival (OS) [74], cancer-specific survival (CSS) and disease-free survival (DFS) [72]. PNI is also an independent factor in CRC recurrence, points to a more malignant tumor phenotype and, as an important parameter, should be considered in pathological classification of CRC [70]. Recently, a large cohort study indicated that PNI is also more commonly observed in colitis-associated (90\%) than in sporadic CRC [73].

\subsection{Functional Innervation Disorders in CRC}

Functional disorders in CRC and colitis concern mostly changes in interactions between large intestine innervation and the immune system [52,67]. Interestingly, such alterations occur on the level of NP-Rs, present on most of the immune cells. Anti-inflammatory roles of VIP and CGRP, as well as pro-inflammatory effects of serotonin and NPY, are also often underlined. In turn, SP has both anti- and pro-inflammatory effects. Apart from neurons, the production of Nts: ACh, choline acetyltransferase (ChAT), acetylcholinesterase, and both muscarinic/cholinergic and nicotinic ACh receptors, was also demonstrated on numerous immune cells (e.g., T and B cells, dendritic cells, macrophages), potentially extending the anti-inflammatory action of $\mathrm{ACh}$ in the large intestine [75].

Influence of some ANS Nts (e.g., NE, ACh) and their co-transmitters (e.g., NPY, adenosine triphosphate and/or VIP) on the proliferation of Intestinal Epithelial Stem Cells (IESCs) is also often underlined, despite little knowledge on the mechanisms of that process [52,76]. It seems that regulation of IESCs proliferation occurs with the participation of both branches of ANS, independently of ENS. Due to more numerous IESCs in the deeper regions of intestinal crypts, SNS and Nts can regulate the proliferation of these cells. ACh is also a PNS mediator, initiating a signaling cascade resulting in suppression of cyclin D1 and a downstream decrease in cell proliferation [76]. The role of ANS-IESC interactions is also considered in the context of differentiation of some kinds of colon cancers from somatic SCs, as well as maintenance of IESC-like properties under neoplastic conditions $[76,77]$.

\section{NPs and Their Mechanisms of Action in Pre-Cancerous Alterations and Colonic Inflammation}

Up to $3 \%$ of CRC arise as a consequence of IBDs [78]. The source of many acute and chronic IBDs, caused by disorders of the brain-gut mucosa axis, are stress factors $[50,52,58,79,80]$. The main effects of stress on intestinal physiology are already the subject of many excellent reviews $[62,80]$ and the participation of NPs, e.g., Corticotropin-releasing Hormone/Factor (CRH/CRF), NT, SP and VIP, in the pathogenesis of IBD is underlined [52,58,79,81-84].

The role of NTs/NPs in pathogenesis of inflammatory-associated CRC was also proven [52,62,75,84-89]. It needs to be noted that the action of NPs produced typically in the upper GIT portions (e.g., CGRP, NT, SP, VIP), studied in different models of colitis or on non-transformed colonocytes, can have both pro-inflammatory (NT, NPY, SP) and anti-inflammatory (CGRP, VIP) effects [52,89]. The role of fat-colonic mucosa interactions in IBD, with the participation of SP and its receptors: neurokinin 1 (NK-1R) and NK-2R, is described by some interesting research examples. An increase in production of mRNA of both SP receptors was observed in IBD mesenteric fat preadipocytes, while the levels of SP mRNA rose in ulcerative colitis (UC) preadipocytes. Moreover, the action of SP via NK-1R resulted in a release of interleukin (IL)-17 in Crohn's disease (CD) and UC preadipocyte and IL-17R in IBD colon biopsies [83].

An especially important role in the development of acute intestinal inflammation is attributed to the neurotensinergic system (NT/NTSRs) [58,87-92]. Studies of the mechanism of NP action in colonic inflammation point out that both NT [87] and SP [86] mediate the acute phase of intestinal inflammation in vivo, inducing production of pro-inflammatory IL-8 cytokine by colonocytes. Furthermore, NT stimulates the expression in mesenteric fat depots [89]. An increase in NT/NTSR1 mRNA was also detected in the mesenteric fat of mice with chemically induced colitis [93]. The actions of SP and NT occur through a mechanism of phosphorylation and degradation of Nuclear Factor-kappaB (NF-kB), as well as phosphorylation of p65, with the participation of conventional Protein Kinase C 
(PKC) [87], or in the case of SP-isoform PKC delta [86]. It was also proven that the pro-inflammatory signaling pathway mediated by NT/NTSR1, with the participation of Matrix Metalloproteinase (MMP)-mediated release of Tumor Necrosis Factor (TNF)- $\alpha$, transactivates Epidermal Growth Factor Receptor (EGFR), followed by the Mitogen-activated Protein Kinase (MAPK, MAP) pathway, increasing the expression of IL-8 in human non-transformed colonic epithelial NCM460 cells [90]. Studies on an animal model (rats) reported that NT, as a pro-inflammatory factor in the large intestine, also takes part in SP-dependent mast cell degranulation and is a key NP in the pathogenesis of Clostridium difficile-induced colonic inflammation $[85,90]$. Other research points to transactivation of the Insulin-like Growth Factor Receptor Type I (IGF1R) pathway by NT, resulting in combined effects of serine-threonine protein kinase AKT (AKT1) phosphorylation and NF- $\mathrm{KB}$ activation. These pathways participate both in pro-inflammatory and tissue repair signaling in colonic epithelial cells and can also play a role in IBD pathogenesis [94]. NT participates in the regulation of various enteric interactions with other systems, such as the CNS and neuroendocrine system. In intestinal carcinogenesis, the enterotrophic and enteroprotective effect of NT/NTSR system dysfunction on epithelial cells was also considered [89].

An important role in chronic stress and regulation of persistent inflammation, hence colon carcinogenesis, is played by the CRH (CRF) family of NPs. These group of peptides also includes urocortin I (Ucn1), II (Unc2), III (Unc3), CRH-binding protein (CRH-bp) and two distinct CRH receptors (CRHR1 and CRHR2), belonging to the GPCRs family [79,82,84]. Local expression of all of the CRH family components was observed in normal and inflamed colon and rectum. It was mostly localized in cells of MPs, submucosal ganglia, glial cells and nerve fibers, as well as non-neuronal components (e.g., smooth muscle cells, endothelial cells (ECs), mononuclear cells of lamina propria mucosae, and goblet cells in colonic epithelium). The role of the CRH family in the inflammatory process in vivo imitates changes resulting from stress exposure (e.g., colonic transit, motility, proto-oncogene Fos expression in myenteric neurons, visceral hypersensitivity and defecation), while treatment of in vitro cultured cells with CRF peptides confirms their participation mostly in secretomotor and mucosal alterations $[79,84]$. The mechanism of CRH family action is mostly based on the regulation of the local immunological profile [84]. Many authors point at the dual role of the CRH-CRHR signaling pathway in colon cancer tumorigenesis, progression and metastasis, with the role of both pro- and anti-inflammatory pathways [95-98]. CRHR2/Ucn2 signaling inhibits tumor growth and metastasis through downregulation of endogenous IL-6/IL-6R expression, reduction of STAT3 phosphorylation mediated by this cytokine, as well as inhibition of STAT3 in CRC cells, resulting in a block of expression of genes regulated by STAT3, as well as inhibition of cell cycle and EMT $[96,98]$. Additionally, the expression of Fas ligand in CRC cells was correlated with a loss of CRHR2 mRNA, poor tumor differentiation and high risk for distant metastases (including LM) [96]. CRHR2/Unc2 signaling turned out to also be a negative regulator of cell resistance to Fas/FasL-apoptosis in CRC via targeting the miR-7/YY1/Fas [98]. More importantly, activation of the CRH/CRHR1 most often leads to the promotion of inflammation, and upregulation of CRHR2-to an opposite response (anti-inflammatory). The pro-inflammatory action of the CRH system in the intestine occurs through a direct influence on immune cells (adaptive immunity), as well as cytokine production. The anti-inflammatory actions of CRH, Ucn1 and Ucn2 may also occur as a result of Toll-like Receptor 4 (TLR4) expression regulation, as is a part of the innate immunity [84].

\section{Basic Steps of Colorectal Cancer Metastasis-Role of Neurotransmitters, Neuropeptides, and Neurotrophins}

\subsection{Proliferation, Migration, and Invasion of CRC cells}

The first step in the invasion-metastasis cascade is the local invasion of tumor cells into the surrounding matrix, with the last step being the colonization of distant organs [21]. Uncontrolled proliferation, excessive migration and invasion of cancer cells are critical phenomena in the first step of CRC metastasis. Only a limited number of cancer cells can migrate to vital organs 
(e.g., liver, lungs and brain). Hence, the study of factors and mechanisms affecting the metastatic potential of these cells is also of great importance in relation to CRC LM [99].

\subsubsection{Neurotransmitters (Nts)}

Among the classic Nts, the most studied for a potential role in the first step of CRC metastasis are: acetylcholine $(\mathrm{ACh})$, norepinephrine (NE) and serotonin (5-hydroxytryptamine, $5-\mathrm{HT})$. The promigratory effect of NE on the migration of the human SW480 colon carcinoma cells (CCcs) was mediated by numerous $\beta 2$-adrenoceptors ( $\beta 2$-AR) via tyrosine kinase activity [100]. In the case of ACh, increased proliferation of CCcs was mediated by transactivation of EGFRs, as well as through MRs (CHRM) [99,101,102]. Particular attention is paid to the role of the CHMR in CCc proliferation, survival, migration, invasion and metastasis. Detailed studies on H508 CCcs (expressing solely M3Rs) and SNU-C4 (expressing solely EGFR) showed that the mechanisms of this transactivation, resulting in increased proliferation of CCcs, are based on MMP7-catalyzed release of Heparin-binding EGF-like Growth Factor (HB-EGF). ACh-induced activation of EGFR and downstream Extracellular Signal-regulated Kinase (ERK) signaling also regulates transcriptional activation of MMP7 [101]. Other research reports that incubation of $\mathrm{H} 508$ cells with ACh resulted in a three-fold increase in cell migration, similar to that invoked by EGF action. Furthermore, ACh-induced HT-29 cell invasion was blocked by atropine [99]. Studies of CHRM agonist action in HT-29 and H508 cells, and in vivo models, proved their common functional interactions with CHRM through the stimulation of MMP1 expression, and deoxycholyltaurine-induced cell invasion [102]. Later research also indicated a role of ACh in post-M3R signaling pathways, increasing MMP1 expression and driving CCcs invasion. It was shown that ACh stimulated robust phosphorylation of p38 MAPK, which was EGFR-independent and could be blocked by PKC- $\alpha$ inhibition [103].

It has been reported that 5-HT is a key mediator of the growth of colon carcinoma allografts in vivo [104]. Studies on 5-HT receptor 3A (HTR3A) knockdown in the six CCc lines showed inhibition of their proliferation and colony formation, resulting in cell cycle arrest and the promotion of cell apoptosis [105]. Other studies confirm the role of serotonin and its receptors (5-HT(1B), 5-HT(3), 5-HT(4)) in enhancing CRC growth. Serotonin and its receptors' agonists increase proliferation and growth of cells, and with the use of selective antagonists, inhibits proliferation and promotes HT-29 cells apoptosis $[106,107]$. In relation to mechanisms connected with CRC distant metastases, it was reported that tumor invasion occurs through the activation of the Axin1/ $\beta$-catenin/MMP7 signaling pathway and 5-HT(1D)R. This receptor, by targeting Axin1 and dissociated $\beta$-catenin from the complex, activated $\beta$-catenin/Lymphoid Enhancer-binding Factor 1(LEF1)/T-cell Factor 4 (TCF4)/MMP7 signaling in CRC metastasis. Activation of 5-HT(1D)R directly induces cell invasion and migration both in vitro and in vivo, while its inhibition has a potent anti-metastatic effect via the Wnt pathway [108].

\subsubsection{Neuropeptides}

Angiotensin II (ANG II)

In vitro research indicated promotion of growth, invasion and anti-apoptotic effect after the stimulation of CCc lines with ANG II (HT-29 and CT26) or angiotensinogen (ATG) (HT-29). It was also proven that hyperglycaemia induced ANG II activation in CCcs. Additionally, it was observed that a decrease in ATG production in the liver, mediated by cholesterol-conjugated antisense S-oligodeoxynucleotide, suppressed LM of HT-29 cells [24]. Other authors showed an increase in migration of other human CRC cells (DLD-1 and LIM2405) as a result of ANG II action via both receptor types (AT1R and AT2R) [109]. 
Endothelins (ETs)

Endothelins (ETs) include ET-1, ET-2, and ET-3, ET-A and ET-B receptors (ETAR and ETBR) (GPCRs family) with clearly defined functions, and upstream processing enzymes such as ET converting enzyme (ECE) [110]. ET-1 is an NP in the human colon with binding sites on neural plexuses and mucosa. In the 1990s, specific ET-1 binding sites were localized in the stromal tissues, including tumor vessels, fibroblasts and nerve fibers in human CRC. Hence, it has been suggested that ET-1 might play the roles of both mitogens and neurotransmitters through paracrine action [111]. For many years, ET-1 was investigated in the context of its impact on cancer progression (including CRC), as well as a potential antagonist of ET receptors in the therapy of various diseases [112,113]. A role of the ET/ETAR axis was also proven in the process of cancer spread and metastasis (including CRC LM) $[112,114,115]$. ET-1 production was detected in many human CCc lines [116]. In a rat LM model, a role of this NP in the promotion of tumor growth via ETAR was reported [117]. In vitro research (SW480 and SW620 cells) confirmed the role of ETAR in promotion of CRC LM. The effects of ET-1 on CCc survival, invasion and MMP-2 expression, occur through a phosphatidyl-inositol-3-kinase (PI3K)-mediated mechanism [115]. It has been recently demonstrated that enhanced proliferation, migration and survival of multiple CCcs via ET-1 also occurs through ETAR, in the mechanism of activation of YAP/TAZ, two transcription coactivators of the Hippo tumor suppressor signaling pathway [118].

High expression in the mouse colonic epithelial cells, both in healthy animals and those with experimental-induced colitis, also concerns ET-2. This NP was also observed in nerve fibers and MPs of the muscle layer, co-expressing with VIP [119]. The role of ET-2 and ET-3 in CRC progression is less recognized. However, it was reported that increased expression of both these peptides significantly weakens migration and invasion of human CCcs [110].

Galanin (Gal)

Gal/galanin receptor 1 (GalR1), as a novel receptor-ligand system that regulates CRC cell survival and drug resistance, was reported [120]. It was also suggested that at least a part of CRC cells with high Gal expression is more malignant and probably responsible for tumor recurrence. The positive correlation between high Gal expression and tumor metastasis, together with the aggressive behavior of CRC cells with high NP expression, might indicate the potential role of Gal in the spread of cancer stem cells (CSCs) in stage II CRC [121].

\section{Gastrin/Progastrin}

Progastrin (PG), gastrin and CCK act through the cholecystokinin-2 receptor (CCK2R, CCK-BR, CCK-B). Activation of CCK2R by gastrin stimulates a rapid tyrosine phosphorylation of the Focal Adhesion Kinase (FAK) pathway in CCcs (Colo320) [122]. Further studies confirmed the role of CCK2R in the regulation of invasiveness and motility of CRC cells [123]. The mouse research model also showed that autocrine/paracrine secretion of PG can promote proliferation of colonic epithelial cells indirectly due to stimulation of colonic myofibroblasts for production of IGF2 [124]. A pioneering study on the immature PG-derived peptide called Glycine-extended Gastrin (G17-Gly) reported that it can stimulate the invasiveness of CCcs. G17-Gly administration significantly enhanced the LoVo cells migration [125]. Other research isolated a novel splice variant of CCK-BR (CCK-BRi4sv) regulating intracellular free $\mathrm{Ca}^{+2}$ and CCcs proliferation though a gastrin-independent mechanism [126].

The potential role in CRC cell invasion and metastasis was also reported in studies on Colo320WT cells with mature G17. This peptide increased $\beta$-catenin expression [127] and activated the $\beta$-catenin/TCF-4 pathway, which leads to high expression of c-Myc and cyclin D1 [128]. Stimulation of HT-29 cells by G17 also caused an increase in phosphorylation of ERK1/ERK2 and AKT, increased Cyclooxygenase-2 (COX-2) expression, Prostaglandin E2 (PGE2) production and DNA synthesis, which resulted in cell growth [129]. Enhanced proliferation of colonic cells in vivo by non-amidated G17-Gly, as well as a second immature PG-derived peptide, C-terminal flanking peptide (CTFP), was confirmed 
in mice model of liver metastasis. However, CTFP does not seem to influence xenograft growth or the incidence of LM [130]. In turn, in the case of mouse colon cancer stem/progenitor cells in vitro, an increased proliferation through PG/G protein-coupled receptor 56 (GPR56) and PG/CCK2R systems was reported [131].

Neuromedins, Neuropeptide Y (NPY) and Substance P (SP)

Pro-proliferative effect in normal colon epithelial cells [132] and CCcs is exhibited by several NP/NP-R systems, e.g., GRP/GRPR [133-135] neuromedin B (NmB)/NMBR [136], NPY/NPY receptors (Y1, Y2, Y3, Y4, and Y5) [137] and SP/NK1R [138].

The family of neuromedins (Nms) consists of GRP, NmB and GRP18-27 (NmC) (bombesin-like peptides), NmK (neurokinin B), NmL (neurokinin A or neurotensin (NT)), NmN, NmS and NmU $[135,139]$. Three types of mammalian Nms (GRP, NmB and NmC) activate the bombesin receptors (BnRs) (GRPR (BB2), NmBR (BB1) and orphan receptor subtype 3 (BRS-3) (BB3)) [135,139,140]. An increase in HT-29 cell proliferation was obtained after $24 \mathrm{~h}$ of incubation with bombesin, GRP, $\mathrm{NmB}$ and $\mathrm{NmC}$, due to their interaction with the GRP receptor [141]. The recent studies showed that overexpression of long noncoding RNAs (lncRNA), LINC01555 in CRC tissues, reinforced CCcs invasion through upregulating the expression of $\mathrm{NmU}$ [30]. The studies showed co-expression of $\mathrm{NmB} / \mathrm{NmBR}$, as well as autocrine action of this system in enhancing proliferation in normal (NCM-460 cells), as well as CCcs (Caco-2 and HT-29). Additionally, it was observed that NmB is $50-100 \%$ more effective in pro-proliferative activity on tumor cells compared to GRP [136]. Enhanced migration and proliferation of epithelial cells in rat intestinal cell lines-18 and Caco-2 monolayers is also caused by CGRP, acting via mast cells [55].

Normal human and mouse colonocytes do not express GRP/GRPR, but both components of this system exhibit differential expression in CRC and CCc lines [133-135,142]. GRP alone shows mitogen as well as morphogen activity, whereas the GRP/GRPR system regulates the histological progression of CRC in mice by promoting a well-differentiated phenotype [133]. The dependence of heterochromatin protein $1 \mathrm{Hs} \beta$ expression on GRP/GRPR signaling was also shown. Inhibition of $1 \mathrm{Hs} \beta$ caused increased invasiveness of human CCcs [143]. In vitro studies (Caco-2 and HT-29 cells) of the mechanisms of tumor cell metastasis showed that GRP promotes tumor cell motility and attachment to ECM, as a result of upregulation of Intercellular Adhesion Molecule-1 (ICAM-1) via FAK [144]. The mechanism increasing CRC migration via GRP/GRPR activity also includes G $\alpha 13-P R G-R h o A-R O C K$, as well as Cox-2/PGE2 signaling pathways [145]. The nonamidated derivatives with pro-GRP C-terminus also manifested the pro-proliferative activity in the colonic mucosa in in vitro (DLD-1, HCT15, HCT116, HT-29), as well as in vivo conditions [146].

The Nm family also includes components of the neurotensinergic system (NT/NTSRs), the role of which in various cancer tumorigenesis (including CRC) is undisputed and reviewed [147-151]. The role of this system in CRC LM is less known. However, a role of the endocrine form of NT was described in the stimulation of growth of many CCc lines (SW480, SW620, HT-29, HCT116 and CI.19A), characterized with NTSR1 expression [152]. In HT-29 cells, the involvement of a complex of two structurally different receptors: NTR1 (GPCR family) and NTSR3 (type I receptor with a single transmembrane domain), was proven in the modulation of the MAPK pathway after NT stimulation and phosphoinositide (PI) turnover mediated by the NTSR1 [153]. Interestingly, it was proven in HT-29 and HCT116 cell lines that NT stimulates MAPK phosphorylation and cell growth through a pathway which does not involve EGF and IGFR systems [154]. Wang et al. showed that administration of sodium butyrate (NaBT), a Histone Deacetylase Inhibitor (HDACi), prevented NT-mediated induction of genes promoting cell proliferation and invasion (e.g., c-Myc, COX-2 and IL-8) [155]. Mouse model studies also showed promotion of tumor growth through stimulating action of NT/NTSR1 on the expression of miR-21 and miR-155 in colonocytes via AKT and NF-KB signaling [156]. Kim et al. showed differential expression of NT/NTSR1, lack of NTSR2 mRNA expression and consistent NTSR3 
mRNA expression in all examined CCc lines, as well as promoter methylation of NTSR1/2. The role of NTSR1 in CCcs proliferation and migration was confirmed using an NTSR1 antagonist (SR48692) [157].

According to some reviews, the NT/NTSR1 system regulates different steps of CRC metastasis through three main signaling pathways (IP3/Ca ${ }^{2+} / \mathrm{PKC} / \mathrm{MAPKs}$, MMPs/EGFR/MAPKs (PI3K/AKT), or Rho-GTPases and non-receptor tyrosine kinase pathways [149]).

In relation to NPY, it was proven that the proliferation of intestinal epithelial cells is promoted via $\mathrm{PI} 3 \mathrm{~K} / \beta$-catenin signaling and downregulation of miR-375-dependent apoptosis in these cells [137].

Almost two decades ago, it was reported that the proliferation of normal human colonic cells in response to SP is a result of NK1R activation via proinflammatory cytokines (IFN- $\gamma$, TNF- $\alpha$ and IL-1 $\beta$ ). This effect was reversed by an NK1R antagonist (Spantide 1) [140]. Similarly, in human CCcs (LiM6 and DLD1), a block of NK1R using another antagonist (the clinical drug aprepitant) also caused significant growth inhibition. Blockage of the SP/NK1R signaling resulted in inhibition of canonical Wnt signaling [138].

Vasoactive Intestinal Polypeptide (VIP)/Pituitary Adenylate Cyclase-Activating Peptide (PACAP)

VIP/PACAP, together with their receptors (VPAC1, VPAC2/PAC1), can also promote growth and proliferation of normal and cancer cells [46,158-160]. Pro-proliferative effects of 5-day incubation with VIP, obtained from CRC patients, was observed on the Colo320DM cells [158]. The pro-proliferative effect of VIP in HT-29 cells was noted via the mechanism of induction of the cAMP-Rap1/Ras-B-Raf-ERK pathway [160].

A potential role in CRC growth has also been attributed to PACAP, which increases the number of viable cells and regulates FasR expression in HCT8 cells [159].

\section{Corticotropin-Releasing Hormone/Factor (CRH/CRF)}

A dual role of CRH/CRHR signaling was described in CRC and metastasis [96,97]. CRHR2/Ucn2 signaling inhibits CRC cell proliferation, migration, invasion and colony formation. Thus, CRHR2 downregulation is associated with a higher risk of distant metastases (including LM) [96]. By contrast, regarding CRH/CRHR1 signaling, a pro-inflammatory and, therefore, tumor-promoting effect, was observed in colitis-associated cancer [161]. Research on the detailed mechanisms of this process showed that CCc proliferation occurs through an IL-6/JAK2/STAT3-dependent mechanism and VEGF-induced tumor angiogenesis [97].

\section{Glucagon (GCG) and Glucagon-Like Peptide 1 (GLP1) and GLP2}

GCG promotes the proliferation of human and CRC cells in vitro and in vivo through binding to GCG receptor (GPCRs family). The downstream signals of GCGR include an activator of AMP-activated protein kinase (AMPK) and MAPK pathways, governing the development and progression of CRC [162].

GCG is cleaved into GLP1, GLP2 and other small peptides in intestinal L cells and brain neurons. Both of the peptides function in small intestine contractility and growth, while GLP2 stimulates mucosal enterocyte proliferation $[60,163]$. The use of GLP1 receptor (GLP1R) antagonist (exendin-4, Ex-4) resulted in a reduction of growth and survival in mouse CT26 CCcs via an increase of intracellular cAMP levels and inhibition of GSK3 and ERK1/2 signaling. Additionally, Ex-4 induced apoptosis, inhibited proliferation and caused changes in the morphology of cultured cells [164]. A weaker proliferation of the same mouse cells after Ex-4 application was confirmed by recent studies. However, in the human CCc lines (Colo320, Caco-2, HT-29, SW480 and LoVo), it was proven that this agonist did not enhance the proliferation and migration of these cells [165].

GLP2, as a main nutrient-responsive NP, functions in promoting cell proliferation and survival through CRC-related molecular pathways [166-168]. It was reported that GLP2 promotes an increase of mucosal colonic neoplasm in mice [169]. Activation of GLP2R directly stimulates protein synthesis by activation of the PI3K/AKT-mTOR pathway. GLP2 action on proliferation and growth of the intestinal 
epithelial cells appears to be indirect, being dependent on IGF1R signaling [166] and occurring through increased IGF1/2 expression in myofibroblasts [170].

Somatostatin (SM)

SM is produced by the CNS and PNS, EECs, inflammatory and immune cells, as well as many cancer cells. It has an inhibitory effect on cell motility and proliferation (G1 cell cycle arrest) and induces apoptosis [171-173]. SM acts through 5 receptor subtypes (sst1-sst5) (GPCR family) expressed by many normal and malignant cells $[56,171]$. In a study on Caco-2, HT-29 and HCT116 cells, expression of sst3/4/5, sst3/5 and sst2/3/5 respectively, was detected. The inhibitory effect of SM on the proliferation of CCcs was based on COX-2 downregulation via activation of two receptors: sst3 or sst5 [129]. Interesting studies on the interactions between SM-positive EECs and adjacent colonic SCs in crypt stem cell niche, indicated that the sub-population of aldehyde dehydrogenase (ALDH)-positive SCs is regulated by sst1 via a paracrine mechanism [174]. The impact of SM on uncontrolled CCcs proliferation and the potential role in CRC progression (including LM) can be explained by the genetic/epigenetic changes of the SM gene in CRC (which will be discussed later).

\subsubsection{Neurotrophins (Ntt)}

Ntts include five structurally related growth factors: NGF, BDNF and neurotrophin $3,-4$ and -5 (Nt-3, -4, and -5) [175-177]. This family of small proteins produced by neurons is associated with survival of sympathetic and sensory neurons, acting through TrKA, TrKB and TrKC (Receptor Tyrosine Kinases (RTK) family) and p75 neurotrophin receptor (p75NtR; TNF receptor family). The latter is often a downregulated tumor suppressor, as opposed to other commonly upregulated TrKs (and their ligands), acting as oncogenic factors [177]. Further, probable tumor suppressors also include TrKC [178] and the $\mathrm{Nt}-3$ receptor (NtRK3) [179], with genetic and epigenetic changes causing their activation in CRC.

Numerous studies on the mechanisms of $\mathrm{Ntt}$ action in CRC progression (including the first step of metastasis) are focused on $\operatorname{TrKB}[176,180-184]$. It was proven that $\operatorname{TrKB}$ mediates production of endogenous BDNF with some differences, depending on cell lines (WiDr, SW480, SW620 and Colo205), inducing proliferation and cell survival, as well as inhibiting apoptosis [180]. Ntt activate Ras, PI3K, phospholipase C- $\gamma 1$ and MAPK pathways $[175,176]$. It was shown that both receptor types (TrKB and $\operatorname{TrKC}$ ) induce cell growth and invasion, as well as function as anti-apoptotic factors [182]. Similarly, BDNF itself increased viability, migration, invasion and inhibited anoikis (detachment-induced apoptosis) in the CCcs [183].

The schematic diagrams of the main signaling pathways regulated by $\mathrm{Nts} / \mathrm{Nps} / \mathrm{Ntt}$, as well as downstream signaling of their activated receptors, which are correlated with proliferation, cell cycle progression, migration and invasion of CRC cells, are shown in Figure 1.

In summary, the knowledge on the impact of selected Nts/NPs/Ntt on increased cell proliferation, migration and invasion of colon tumor cells is based on animal models, as well as in vitro studies using adequate assays and human (e.g., HT-29, H508, SNU-C4, DLD-1, LIM2405, SW480, SW620, Colo320, LoVo, HCT116, HCT8 and Colo205) or mouse (e.g., CT26) colon/colorectal adenocarcinoma cell lines with different metastatic potential. Most of the studies use HT-29 cells and their variants (WiDr, CI.19A), in which the presence of $\mathrm{Nt} / \mathrm{Np} / \mathrm{Ntt}$ receptors was confirmed. Most of the in vitro studies indicate a potential role of many neuroactive molecules in the metastatic process of CRC in vivo. Basic mechanisms of cell signal transduction involving Nts/NPs/Ntt were described, playing a major role in the regulation of genes important for CRC progression (including LM) (e.g., c-Myc, cyclin D1, COX-2, IL-8, MMPs, LEF1/TCF4)). 


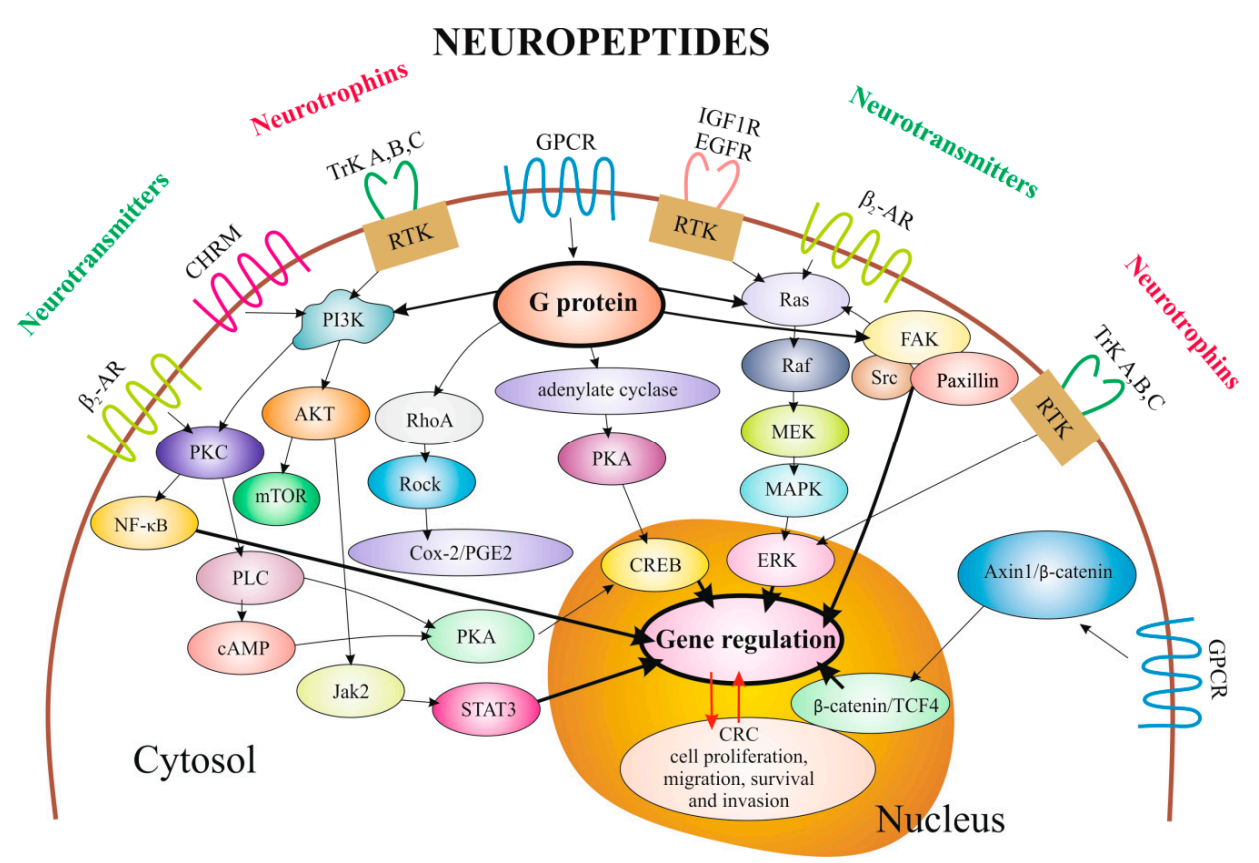

Figure 1. The schematic representation of the major cellular components and signaling pathways regulated by Neurotransmitters, Neuropeptides and Neurotrophins and their Receptors ( $\beta 2$-ARs, CHRMs, GPCRs, IGF1R/EGFR, TrKs), involved in a the first step of invasion-metastasis cascade in colorectal cancer cells, promoting CRC progression (including CRC LM). Abbreviations: Receptors: $\beta 2-\mathrm{AR}-\beta_{2}$ adrenoreceptor; CHRM-Cholinergic/Acetylcholine Receptor; EGFR-Epidermal Growth Factor Receptor; GPCR-G Protein-coupled Receptor; IGF1R-Insulin-like Growth Factor Receptor type I; RTK-Receptor Tyrosine Kinase; TrK A, B, C-Tropomyosin-related Kinase A, B, C; Intracellular enzymes: AKT-Serine-threonine Protein Kinase (or PKB); Cox-2-Cyclooxygenase 2; CREB-cAMP response element-binding protein; FAK-Focal Adhesion Kinase; Jak2-Janus kinase 2; MAPK-Mitogen-activated Protein Kinase (called ERK); MEK-Mitogen-activated protein kinase kinase, a kinase enzyme which phosphorylates MAPK; mTOR-the mammalian Target of Rapamycin Kinase; NF- $\kappa \beta$-Nuclear factor kappa-light-chain-enhancer of activated B cells; PI3K-Phosphatidylinositol 3-kinase; PKA- Protein Kinase A, B (AKT), C; PLC-Phospholipase C; Ras-protein from small GTPase family; Raf-serine/threonine-specific protein kinases; RhoA-Ras homolog family member A; Rock-Rho-associated protein kinase; Src-kinase from non-RTK family; STAT3-Signal transducer and activator of transcription 3; Others: CRC-Colorectal Cancer; PGE2-Prostaglandin E2; TCF4-T-cell Factor 4.

\subsection{Colorectal Cancer Cell-Cell and Cell-Extracellular Matrix Loss of Adhesion}

In this process, the participation of the NP/NP-Rs components upregulating MMPs production is especially important. The mammalian MMPs, particularly MMP1, degrade EMC and facilitate CRC cell invasion and metastasis. Their levels correlate with the clinical progression of $C R C$, hematogenous metastases and poor prognosis [102,185]. Production of MMPs (MMP1, MMP2 and MMP3) mediating cell migration was proven in LoVo cells after G-17Gly stimulation [125]. Interestingly, in tissue microarrays (TMA) of CRC LM, MMP1 and MMP2 were identified as consistently under-expressed, compared with primary CRC ( $\mathrm{pCRC}$ ). According to the authors, MMP1 levels in early CRC stages (II and III) were associated with an increased likelihood of distant metastasis, whereas rectal cancer in stage III recurrence was rather associated with MMP2 [186]. In turn, recent studies on serum MMP2 levels showed upregulation of this marker in CRC patients, as well as its correlation with clinical data (including lymph node and liver metastases) [187].

Increase in MMPs production (mainly MMP7 and MMP1) also upregulated expression of the Nts member ACh $[100,102]$.

Furthermore, a study of CRHR2 signaling showed induction of changes in cell-cell junctions in two CRC cell lines (HT-29, SW620), affecting their ability to maintain cell-cell contact via the Src/ERK 
pathway. In HT-29 cells, cell adhesion remodelling, modification of cytoskeleton structures, as well as stimulation of migration and invasion ensued. All these phenomena can promote the metastatic potential of human CRC, resembling the EMT process [188]. In turn, other studies show lower expression of CRHR2 in CRC tissues and cell lines compared to control, suggesting contrasting effects of CRHR2/Unc2 signaling on tumor growth and EMT, with decreased expression of EMT-inducers and elevated levels of EMT-suppressors. In other words, downregulation of CRHR2 in CRC could be responsible for cell spread and be a factor of high metastasis risk [96,98].

Another NP-R with a potential role in this stage of LM is NTSR3 (Sortilin) and its soluble form (sNTSR3/Sortilin) [189]. The presence of Sortilin was proven at cell membranes of numerous cancer cells (including CRC cells) [190]. Specific binding of sNTSR3 and its internalization occurs in HT-29 cells, with a potential mechanism in this stage of metastasis based on activation of the FAK/Src-dependent PI3K pathway, accompanied with an increase in intracellular $\mathrm{Ca}^{+2}$ and a decrease of integrin mRNAs $[189,191,192]$. Hence, sNTSR3 action resulted in modification of desmosome structure, suggesting that these changes might lead to separation and spread of cells in early stages of carcinogenesis, easing metastasis [189,192].

Among neurotrophin receptors, it was shown that downregulation of $\operatorname{TrKB}$ increased anoikis sensitivity of CRC cells in vitro, with TrKB-induced anoikis suppression in CRC cells dependent on the PKB (AKT) signaling pathway. In other words, overexpression of TrKB (as an anti-anoikis molecule) could protect CRC cells from anoikis in the circulatory and lymphatic system [182].

\subsection{Epithelial to Mesenchymal Transition (EMT) in CRC}

EMT is an important process in CRC LM formation [21]. It was recently reported that the GPR56 (GPCR family) is significantly upregulated in some of the CCc lines (e.g., LoVo, DLD-1, SW480, HCT116), compared to control lines (NCM460). However, relatively low expression of GPR56 was detected in HT-29 cells. This peptide promotes CRC cell proliferation, migration and invasion, and is critical in CRC metastasis, due to EMT stimulation via activation of the PI3K/AKT signaling [15].

Another member of NP-Rs, acting on EMT, is ANG II Receptor Type 1 (AT1R). Use of specific AT1R and AT2R blockers caused inhibition of migration of human CRC cell lines (DLD-1 and LIM2405). In turn, ATR1 blocker caused an increase in E-cadherin expression and reduced Zinc finger E-box-binding homeobox 1 (ZEB1) and vimentin, while ATR2 inhibition lowered E-cadherin expression, without changing the levels of ZEB1 and vimentin [109].

Neurotrophin receptors, e.g., TrKB, also participate in EMT induction. In clinical samples, the inverse correlation was described between the expression of $\operatorname{TrKB}$ and E-cadherin. SW480 cell line studies confirmed the alleviation of malignant potential of these cells by TrKB knockdown. TrKB might play an important role in EMT and progression to metastasis [193].

\subsection{Angiogenesis in CRC}

A stimulating (e.g., epinephrine, NE), inhibiting (e.g., dopamine, SM), as well as dual role (stimulating or inhibiting) (e.g., NPY) of Nts and NPs on tumor angiogenesis has been described, which might suggest the role of these molecules in progression and metastasis of tumors (including CRC) [194].

Proangiogenic, as well as pro-inflammatory effects of NT, were demonstrated in an in vitro model (NCM460 cells overexpressing NTR1). These effects in acute colitis were mediated by NTR1-prolyl hydroxylase 2/HIF-1 $\alpha$-miR-210 signaling [92].

Two forms of gastrins (amidated G17 and G17-Gly peptides) were also indicated to increase expression of HB-EGF in Human Umbilical Vein ECs (HUVEC) and microvessel-derived ECs, as well as elevate the levels of MMP2, MMP3 and MMP9. Mean vessel density (MVD) in normal mucosa adjacent to CRC correlated with serum gastrin levels and HB-EGF expression in CRC patients [195]. Pro-angiogenic action of progastrin in CRC was also proven. Stimulation of cadherin phosphorylation in ECs, p125-FAK, paxillin and actin remodelling resulted in EC proliferation/migration, the ability of ECs to form capillary-like structures and enhanced permeability of endothelium [196]. 
Somatostatin is an endogenous inhibitor of both cell proliferation and angiogenesis. Interesting research using in vitro receptor autoradiography in submucosal and subserosal vessels localized near human CRC showed 3-5-fold overexpression of SM and SP receptors in the host veins within a close area ( $2 \mathrm{~cm}$ wide) surrounding human $\mathrm{PCRC}$, as compared with veins located at a greater distance $(5-10 \mathrm{~cm})$ in control tissue. This finding suggests a regulatory mechanism presence on the levels of tumor vascular bed, which might be crucial for the development of CRC metastasis mechanisms [197].

Another pathway active during the Vascular Endothelial Growth Factor (VEGF)-induced tumor angiogenesis is the CRH/CRHR1 signaling, as one of the mechanisms in colitis-associated CRC [97,161].

A potential role of TrKB, positively regulating the expression of VEGF-A and VEGF-C, was also indicated in an in vitro model [180]. Increased secretion of VEGF-A in mouse rectal CMT93 cells is also caused, in a dose-dependent manner, by AT1R [198].

A list of Nts, NPs and Ntt and their receptors involved in the signaling pathways of the main steps of CRC metastasis (including distant metastasis) is presented in Table 1.

Table 1. Neurotransmitters (Nts), Neuropeptides (NPs) and Neurotrophins (Ntt) and their receptors playing a role in the progression of colorectal cancer (including CRC liver metastasis) and the major mechanisms of action of the neuroactive molecules in the most important steps of cancer metastasis.

\begin{tabular}{|c|c|c|c|c|}
\hline \multirow{2}{*}{$\begin{array}{l}\text { Stage of Liver } \\
\text { Metastasis }\end{array}$} & \multicolumn{3}{|c|}{ Type of Molecule/Receptor } & \multirow{2}{*}{$\begin{array}{c}\text { Mechanisms/Signaling } \\
\text { Pathways }\end{array}$} \\
\hline & Nts & NPs & $\mathrm{Ntt}$ & \\
\hline $\begin{array}{l}\text { Cell proliferation, } \\
\text { migration, survival }\end{array}$ & $\begin{array}{c}\text { ACh } \\
\text { NE } \\
\text { Serotonin } \\
\beta 2-A R \\
\text { CHRM }\end{array}$ & $\begin{array}{c}\text { ET-1 } \\
\text { Gastrin, PG, } \\
\text { G17 } \\
\text { CRH } \\
\text { GCG } \\
\text { GLP1/2 } \\
\text { GRP/GRPR } \\
\text { NT } \\
\text { NPY } \\
\text { SP } \\
\text { VIP } \\
\text { GPCR family }\end{array}$ & $\begin{array}{c}\text { NGF } \\
\text { BDNF } \\
\text { Nt-3,-4-,-5 } \\
\text { TrK A, B, C }\end{array}$ & See Figure 1 \\
\hline $\begin{array}{l}\text { Cell-Cell } \\
\text { weakening and } \\
\text { CEM loss of } \\
\text { adhesion }\end{array}$ & $\mathrm{ACh}$ & $\begin{array}{c}\text { G17-Gly } \\
\text { CRH/CRHR2 } \\
\text { NT/sNTSR3 }\end{array}$ & $\operatorname{TrKB}$ & $\begin{array}{c}\uparrow M M P 1,-2,-3,-7 ; \\
\text { Src/ERK; } \\
\text { FAK/Src/PI3K; } \\
\text { AKT }\end{array}$ \\
\hline EMT & $\begin{array}{c}\mathrm{E} \\
\mathrm{NE}\end{array}$ & $\begin{array}{l}\text { ANG/ATR1/ATR2 } \\
\text { GPR56 }\end{array}$ & $\operatorname{TrKB}$ & $\begin{array}{c}\text { PI3K/AKT; } \\
\text { E-cadherin, ZEB1, vimentin } \\
\text { expression modulation }\end{array}$ \\
\hline Angiogenesis & & $\begin{array}{c}\text { ANG/ATR1 } \\
\text { CRH } \\
\text { G17, G17-Gly, } \\
\text { PG } \\
\text { NPY, } \\
\text { NT/NTSR1 }\end{array}$ & $\operatorname{TrKB}$ & $\begin{array}{c}\text { } \text { VEGF-A, VEGF-C; } \\
\text { Cadherin phosphorylation; } \\
\text { P125-FAK, paxillin, actin } \\
\text { remodelling; } \\
\uparrow \text { HB-EGF; } \\
\uparrow \text { MMP2, -3,-9 }\end{array}$ \\
\hline
\end{tabular}

Legend: ACh—acetylcholine; ANG—Angiotensin; AT1R/2R—Angiotensin 1/2 receptors; $\beta 2$-AR— $\beta_{2}$ adrenoreceptor; CRC —Colorectal Carcinoma; CRHR1/CRHR2 - Corticotropin-releasing Hormone (Factor) Receptors; CHRMCholinergic/Acetylcholine Receptor; CEM-Cell-extracellular Matrix; E-Epinephrine; EMT—Epithelial-mesench ymal Transition; ET/AR/BR—Endothelin/Receptor A/B; FAK—Focal Adhesion Kinase; G-Gastrin; GCG—Glucagon; GLP1/2/R - Glucagon-Like Peptides/Receptor; GPCR - G Protein-coupled Receptor; GPR56-G protein-coupled receptor 56; GRP/R - Gastrin-Releasing Peptide/Receptor; HB-EGF-Heparin-binding EGF-like Growth Factor; MMPs-Metalloproteinases; NE-Norepinephrine; NPY - Neuropeptide Y; NT/NTSR3-Neurotensin/NT Receptor 3; PG—Progastrin; SP—Substance P; TrK A, B, C—Tropomyosin-related Kinase A, B, C; VEGF-Vascular Endothelial Growth Factor; VIP—Vasoactive Intestinal Peptide; $\uparrow / \downarrow$ —significantly increased/decreased.

\section{Role of Circulating Tumor Cells (CTC) in Liver Metastasis}

CTC aggregates (up to 20 cells) from primary tumor sites might be the precursors of tumor metastasis (including LM) [199]. However, research on sensitive and specific CTC markers still poses numerous difficulties. Numbers of these cells in the blood of metastatic patients is insufficient for effective detection 
( $<1$ to $<50$ in $7.5 \mathrm{~mL}$ blood of a metastatic cancer patient), which motivates the search for more modern techniques of their detection, including other panels of cellular markers (apart from epithelial), typical for processes such as EMT, mesenchymal-epithelial transition (MET), with SCs traits, or in an immune evasive state [200,201]. NPs, being the subject of this review, have not yet been indicated as CTC markers.

Recent research shows that regulatory mechanisms of CTC-mediated tumor metastasis involve Tumor-Associated Macrophages (TAMs) by regulating the JAK2/STAT3/miR-506-3p/FoxQ1 axis. The study used different TAMs for evaluation of the associations of their sub-localization with EMT phenotype and ratio of mesenchymal CTC in CRC [202].

\section{Tissue Expression of NP System Components in CRC and Liver Metastasis}

CRC is a heterogeneous tumor, containing, apart from epithelial tumor cells, other cellular populations, e.g., cancer-associated fibroblasts (CAFs) [203], myofibroblasts [204], TAMs [202], B and T cells [205], tumor ECs (TECs) [206] and CRC CSCs [207], which might be a source of NPs and their receptors, playing a key role in CRC metastasis (including LM).

Cellular localization of most of the studied NPs concerns mainly epithelial tumor cells (TCs) [67,114,135,144,146,185,198,208-212], the "stromal" cells [117,208,211], TECs [117,208] and TAMs [95]. Expression was also described in typical EECs [213-215], neurons of submucosal and MPs [67], as well as cells of peritumoral veins surrounding human pCRC [194], or in blood vessels surrounding CRC [95].

A particular prognostic value in CRC is attributed to altered (especially elevated) expression of NPs and their receptors in tumor tissues, compared to control [95,121,135,198,210,212,214,216-219].

Peptides secreted in autocrine/paracrine signaling serve an important role in numerous signaling pathways, responsible for an increase in the concentration of cytosolic $\mathrm{Ca}^{2+}$ and proliferation stimulation [126,211], intensification of CRC migration/invasion [125], enhanced ECs activity in models of angiogenesis [196] or direct pro-carcinogenic effect [220]. Most of the studies of tissue expression, particularly of NP receptors, also suggest their usefulness in the context of CRC therapeutics.

From the studied group of NPs/NP-Rs, some were overexpressed in pCRC tissues compared with control, which might be linked to liver metastases. These molecules include (alphabetically): AT1R [198], BDNF [183], ET-1 [117], galanin [120], gastrin [210], NK-1R and SP [218], progastrin [47], TrKB [181], TrKC [182] and co-expression of BDNF/TrKB [183]. Lack of or significantly lower tumor expression versus control, which might also play a role in LM, was demonstrated for several NP/NP-Rs system components: CRHR2 [96], GRP/GRPR [142,146], SM [221], Sst2 [222], as well as Sst2 and Sst5 [223]. Some authors also observed elevated expression of NPs in PCRC, with lowered levels in metastatic liver (e.g., NmB and GRPR) [135].

Results of studies on the expression of renin-angiotensin system (RAS) components, conducted on murine models of CRC liver metastases, differ from those obtained from human CRC tissues [224,225]. In mouse metastatic liver, a lower expression of ATG and AT1R was observed, with elevated levels of angiotensin I converting enzyme (ACE) and ANG precursors 1-7 (MasR), compared to the surrounding liver. The treatment with captopril (inhibitor of ACE) in CRC metastases resulted in a decrease in LM volume and downregulation of ATG and AT1R expression, with increased ACE expression in the final stages of tumor growth [224]. Moreover, Wen et al. showed an immunomodulatory role of the RAS via liver Kupffer cells (KCs). Application of captopril increased the number of KCs in the LM in vivo and invasion in vitro, as well as appeared to alter the function of early, anti-tumor KCs during tumor progression [225]. In turn, Shimizu et al. showed that ANG II increases the expression of TGF- $\beta 1$ in KCs. In other words, collagen build-up in metastasis area via the AT1a pathway was associated with resident KCs induction [226].

Studies on the role and mechanisms of action of $\mathrm{Nt} / \mathrm{NP} / \mathrm{Ntt}$ receptors in colon carcinogenesis and metastasis started almost three decades ago. They mostly concern NTSR [154,156,227], NmB-R [141,164] and TrK [180-183]. In the 1990s, expression of NTSR was detected in more than $40 \%$ of 19 CRC cell lines, with a lack of its presence in the normal colonic epithelium [228]. Furthermore, membrane localization of two structurally different NTSRs, namely NTSR1 (GPCR family) and NTSR3, as well as 
their internalization after NT stimulation, was described in HT-29 cells [154]. Higher expression of the NTSR1 gene in vivo was observed in colonic adenocarcinoma compared to adenomas. According to the authors, NTSR1 expression might be responsible not only for early stages of CRC development but also for its progression and aggressive forms, as successive NTSR1 tissue expression increase was described from colitis, through dysplasia, to CRC itself [227,229].

When it comes to the research on TrK tissue expression in CRC, the results are consistent for correlation of expression of these receptors with lymph node and peritoneal metastases, with less consistency when it comes to correlation with LM. In one study, only $\operatorname{TrKC}$ expression correlated with LM [182], while in another, this correlation was described for overexpression of TrKB [181]. In another, co-expression of both ligand-receptors, namely BDNF/TrKB, correlated with liver and peritoneal metastases [183]. Higher expression of ligands (BDNF) or TrKs correlated with clinical stage $[180,182]$ and worse prognosis in CRC patients [181,183,193].

In the context of Sst1 to Sst5 expression in CRC and LM, the results vary. Loss of Ssst2 mRNA expression was described in Dukes' stage D CRC and hepatic metastasis patients [222]. Other authors considered elevated Sst2 mRNA expression for a bad prognostic factor, as these patients exhibited shorter DFS [230]. Evangelou et al. described a negative correlation between the level of Sst2 and Sst 5 protein expression in CRC with invasion and LM. In turn, the level of Sst2 expression was higher in lower-grade and rectum-located tumors, with patients with positive expression of both proteins (Sst2 or sst5) surviving longer [223].

\section{Serum Levels of NP System Components in CRC and Liver Metastasis}

Studies of serum concentrations of NP system components in CRC and/or CRC metastases (lymph nodes, liver), were mainly conducted in the context of their prognostic role or application in therapy. An increase in concentrations of Nts (e.g., serotonin) [231] and NPs were mainly observed in pCRC patients compared to control. This observation concerned the following NPs (alphabetically): ET-1 (and big ET-1) [117,208,209,232,233], galanin [67], gastrin/G-17 [234,235], GLP1/GLP2 [236], NT [49,237,238], PYY [236] and SP [239]. Serum VIP concentrations were also higher in metastatic CRC versus control [158].

ET-1 levels were also higher in LM patients compared to those without metastases [208], as well as patients with different types of LM (metachronous/synchronous) compared with control [232]. The systemic plasma levels of big ET-1 were higher in patients with CRC with Dukes' D staging versus localized disease [209]. The levels of big ET- 1 of $>4.2 \mathrm{pg} / \mathrm{mL}$, age of patient $>70$ years and Dukes' stage $C$, were indicated as factors of bad prognosis and independent prognostic values for OS [233]. However, other authors negate the prognostic value of serum ET-1 concentrations in CRC [232,240].

In the context of the role of gastrin/G-17 in CRC progression, the study results are also inconsistent. Some observed elevated concentrations of these peptides in CRC versus control $[235,241]$, while others did not detect such differences [234]. However, significantly higher serum gastrin levels were demonstrated in patients with lymph node metastasis than patients without metastasis [234]. While gastrin concentrations of European CRC patients were higher in the tumor $(>50 \mathrm{pg} / \mathrm{mL})$ than in control, they were not indicated as a CRC risk factor and did not differentiate Helicobacter pylori $(H p)(+)$ and $H p(-)$ patients [241]. In precancerous lesions, some authors did not observe any correlation between hypergastrinemia and adenoma development [242], while others have shown that hypergastrinemia is a risk factor for colonic adenomas [243].

Elevated serum NT concentrations in CRC were indicated as one of the risk factors for colonic polyps or cancers (OR, 2.73; 95\% CI, 1.33-5.59, $p<0.01)$ [238]. In turn, plasma serotonin levels were higher in patients with more severe TNM stages. High serotonin levels were shown to have a statistically independent prognostic value for poor OS and can be useful as a novel prognostic marker for CRC recurrence [231]. In a comparison of VIP concentrations in different metastatic GIT cancers (gastric, pancreatic and CRC), significantly higher levels of this peptide were detected in CRC in relation to both gastric [237] and pancreatic cancers [158]. The results collecting observations on tissue expression and plasma levels of NTs/NPs/Ntt in pCRC and metastatic CRC are shown in Table 2. 
Table 2. Tissue (T) expression, serum (S) levels of NPs and their receptors in CRC, with their potential roles in metachronous (m) or synchronous (s) liver metastasis (LM) [references].

\begin{tabular}{|c|c|c|c|c|}
\hline \multicolumn{3}{|c|}{ Neuropeptides/NP Receptors } & \multicolumn{2}{|l|}{ CRC } \\
\hline Type & Source & Cellular localization & Primary & Liver Metastases \\
\hline $\mathrm{ACE}$ & $\mathrm{T}$ & & $\#, \uparrow$ versus C [244] & \\
\hline BBS, GRP, pro-GRP & $\mathrm{T}$ & $\begin{array}{l}\text { TCs, including signet-ring cells } \\
{[135,142,144,146,212] ; \text { EECs [214] }}\end{array}$ & $\begin{array}{c}100 \%(+) \text { pCRC }[135] ; *,(+)[144] ; \bullet, \#, \downarrow[142,146] ;(+) \\
{[212] ; 30 \% \text { pCRC with intracellular changes }[214]}\end{array}$ & $\begin{array}{l}\text { Aberrantly expressed mRNA } \\
\text { [135]; ND [144] }\end{array}$ \\
\hline CCK2R & $\mathrm{T}$ & $\begin{array}{l}\text { TCs [123]; epithelial TCs (33\%), } \\
\text { non-epithelial cells (39\%) [211] }\end{array}$ & $\begin{array}{l}44.4 \%(+), 26.7 \%(++)[123] ; \text { CCK-BRi4sv in } 50 \% \text { CRC } \\
\text { and } 100 \% \text { polyps [126], } 6 / 8(+)[211]\end{array}$ & \\
\hline $\begin{array}{l}\text { CRHR1, CRHR2 } \\
\text { (CRF1, CRF2) }\end{array}$ & $\mathrm{T}$ & Epithelial TCs (CRF2) [188] & $\begin{array}{c}\bullet, \#, \downarrow \text { mRNA/protein versus C [96]; } \star \text {, } \uparrow \text { Ucn2/3, CRF2 } \\
{[188] ; \text { ND [217] }}\end{array}$ & $\bullet, \#, \downarrow C R H R 2[96]$ \\
\hline ET-1 & $\mathrm{E}$ & $\begin{array}{l}\text { ECs in normal liver [208]; epithelial } \\
\text { TCs }[117,208,209] \text {; TECs }[117,208], \\
\text { nyofibroblasts, stromal cells }[117,208]\end{array}$ & $\begin{array}{l}\uparrow[117] ; \text { microvascular (+) associated with big ET-1 } \\
\text { plasma level [209] }\end{array}$ & $(+)[208]$ \\
\hline ET AR, ET BR & $\mathrm{T}$ & TCs [114] & $\uparrow$ ET AR mRNA, $\downarrow$ ET BR mRNA versus C [114] & \\
\hline \multirow[t]{2}{*}{ Galanin } & $\mathrm{T}$ & $\begin{array}{l}\text { submucosal and MPs cells, TCs, } \\
\text { intestinal epithelium [67] }\end{array}$ & $\#, \uparrow[120,121]$ & \\
\hline & $\mathrm{S}$ & & $\uparrow 2.4 x$ level versus C [67] & \\
\hline \multirow[b]{2}{*}{ G, G17, PG } & $\mathrm{T}$ & $\begin{array}{l}\text { cell membranes of TCs [210]; } \\
\text { epithelial TCs }[123,211]\end{array}$ & •, $\uparrow[47] ; \uparrow[123] ; \boldsymbol{*}, \uparrow[210] ; 39 \%$ (+) cells [211] & $(+)$ [210] \\
\hline & $\mathrm{S}$ & & $\begin{array}{l}\bullet \uparrow(\mathrm{G}) \text { in CRC with lymph node M versus CRC } \\
\text { without M [234]; } \uparrow(\mathrm{G} 17) \text { in CRC versus C [235]; } \uparrow(\mathrm{G}) \\
\text { not associated with any colonic neoplasms [241] }\end{array}$ & \\
\hline
\end{tabular}


Table 2. Cont

\begin{tabular}{|c|c|c|c|c|}
\hline \multicolumn{3}{|c|}{ Neuropeptides/NP Receptors } & \multicolumn{2}{|l|}{ CRC } \\
\hline Type & Source & Cellular localization & Primary & Liver Metastases \\
\hline GCG & $\mathrm{T}$ & TCs [210]; L cells [213]; EG cells [214] & $\uparrow[210] ;(+)[213]$ & \\
\hline GLP1/2 & $\mathrm{S}$ & & $\uparrow / \uparrow[236]$ & \\
\hline GLP2R & $\mathrm{T}$ & $\begin{array}{l}\text { EECs in normal mucosa (GLP2R), } \\
\text { cytoplasm of TCs [215] }\end{array}$ & (+) $20 \%$ CRC; $0 \%$ in polyps [215] & \\
\hline $\mathrm{NmB}$ & $\mathrm{T}$ & TCs and normal epithelium [141] & $\uparrow$ in all but one tumor samples [135]; (+) [141] & $\downarrow$ in LM versus pCRC [135] \\
\hline NmB-R & $\mathrm{T}$ & TCs and normal epithelium [141] & ND [135]; $\uparrow$ versus C; & \\
\hline NK-1R & $\mathrm{T}$ & $\begin{array}{l}\text { Peritumoral host vein cells [194]; TCs } \\
\text { [218] }\end{array}$ & 3-5-fold $\uparrow[194] ;$,\#, $\uparrow$ versus C [218] & \\
\hline NT & $\mathrm{S}$ & & $\begin{array}{l}\uparrow 3.7 x \text { in colon pathology versus C [49]; } \uparrow \text { versus } C \text { and } \\
\text { GC [237]; } \uparrow \text { versus C [238] }\end{array}$ & \\
\hline Pro-GCG, Glicentin & $\mathrm{T}$ & L cells [213] & $(+)[213]$ & \\
\hline \multirow{2}{*}{$\begin{array}{l}\text { PYY, PP/proPP-like } \\
\text { peptides }\end{array}$} & $\mathrm{T}$ & human L cells [213]; TCs of NET [236] & $(+)[213,236]$ & \\
\hline & $S$ & & ^PYY [236]; PYY NS versus C, $\downarrow P Y Y$ versus GC [237] & \\
\hline \multirow{2}{*}{ Serotonin } & $\mathrm{T}$ & EECs [214] & $(+)[214]$ & \\
\hline & $\mathrm{S}$ & & $\downarrow, \#, \uparrow$ versus C and polyps [231] & \\
\hline 5HT3, 5HT4 & $\mathrm{T}$ & & $(+)[106]$ & \\
\hline SM & $\mathrm{T}$ & D cells [214,221]; TCs [221] & *, $\downarrow[210] ; \downarrow[221]$ & \\
\hline Sst1-sst5 & $\mathrm{T}$ & TCs $[222,223,230]$ & $\begin{array}{c}\text { (+) SSt2 mRNA (20-50\% CRC), ND in stage D, and LM } \\
\text { [222]; * (lower grade)- } \uparrow \text { Sst2, } \bullet, \#, \downarrow \text { Sst2 and sst5 [223]; } \\
\#, \uparrow \text { sst2 mRNA [230] }\end{array}$ & $\begin{array}{l}\text { Sst2 mRNA ND in LM [222]; } \\
\text { Sst2 and sst5-negative } \\
\text { correlation with LM [223] }\end{array}$ \\
\hline
\end{tabular}


Table 2. Cont.

\begin{tabular}{|c|c|c|c|c|}
\hline \multicolumn{3}{|c|}{ Neuropeptides/NP Receptors } & \multicolumn{2}{|l|}{ CRC } \\
\hline Type & Source & Cellular localization & Primary & Liver Metastases \\
\hline \multirow{2}{*}{ SP } & $\mathrm{T}$ & \multicolumn{3}{|c|}{ 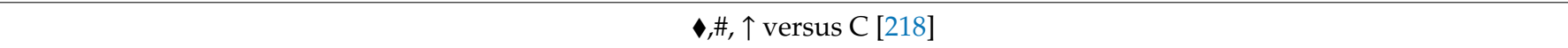 } \\
\hline & $\mathrm{S}$ & \multicolumn{3}{|c|}{$\uparrow$ levels versus C [239] } \\
\hline $\operatorname{TrK}$ & $\mathrm{T}$ & $\begin{array}{l}\text { TCs of pCRC and peritoneal } \\
\text { metastases [183] }\end{array}$ & 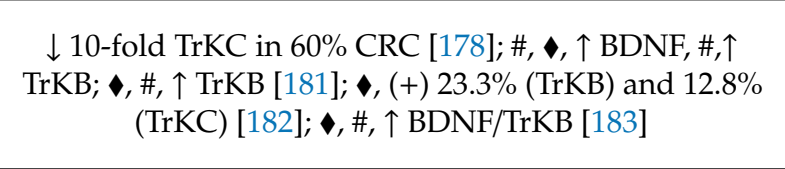 & $\begin{array}{l}\uparrow T r K B \text { related to distant M [181]; } \\
\text { TrKC related to LM [182]; BDNF } \\
\text { alone, and BDNF+TrKB } \\
\text { associated with LM [183] }\end{array}$ \\
\hline \multirow[t]{2}{*}{ VIP } & c & $\begin{array}{l}\text { cell membranes of signet-ring cells } \\
\text { [212]; EECs [214] }\end{array}$ & \multicolumn{2}{|l|}{$(+)[212,214]$} \\
\hline & $S$ & & NS versus C, $\uparrow$ versus GC [237] & $\uparrow$ versus C [158] \\
\hline VPAC1 & TC & $\begin{array}{l}\text { TCs, blood vessels near CRC, TAMs } \\
\text { [95]; mucosal cells [216] }\end{array}$ & *, $\uparrow$ VPAC1 [95]; (+) 96\% CRC [216] & \\
\hline \multicolumn{5}{|c|}{ 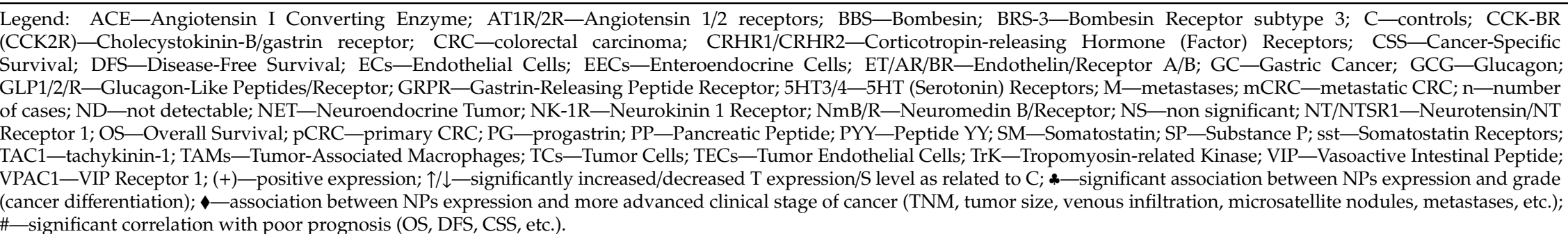 } \\
\hline
\end{tabular}




\section{Genetic and Epigenetic Changes of Selected NPs and CRC Liver Metastasis}

Profiles of many genes responsible for CRC development, and most probably associated CRC LM, were described. However, there is a lack of knowledge on LM-specific mutations that could be applied in everyday medical practice [245-251]. According to some authors, combinations of oncogenic changes are more important than specific events that determine the metastatic genotype of tumor cell early in carcinogenesis $[245,248]$. Although some of the papers comparing the genetic changes in pCRC and metastatic tumors, or advanced stages of CRC versus small tumors with less metastatic potential did not show significant changes in the Nt/NP/Ntt genes $[246,247,249,251]$, there are some reports of such changes $[245,250,252]$.

In the study of Koehler et al., among 23 up- and down-regulated transcripts in the high-stage and low-stage CRC group, upregulation of Ntt-3 precursor (BDNF, NGF2) was described [245]. Lim et al. defined 3 classes of gene mutations in $\mathrm{CRC}$, assessing the presence or absence of mutations during LM development. Around $60 \%$ of changes were classified as Class 1 (shared between primary tumor and LM), which suggests the clonal origin of the primary tumor and LM. This research indicated 11 mutation-associated splicing events in the LM transcriptomes, including the splite-site GPR56 mutation, which can result in a premature stop codon for all functional domains of GPR56 (tumor-suppressor) and be responsible for CRC development. Although the analysis shows several interesting changes at the exome and transcriptome levels, the authors did not indicate significant LM-specific mutations [250]. Interestingly, among the differentially expressed mRNA (DEMs) in CRC, was a GRP, a significant increase of which could serve as an independent DFS prognostic gene [252].

The most common epigenetic alterations in CRC include aberrant methylation of DNA [178,179,253-257]. Hyper- or hypo-methylation might serve as an epigenetic biomarker for early detection, prognosis and response to chemotherapy in CRC [244,258,259]. The only, as of now, epigenetic marker approved by the US Food and Drug Administration (FDA) for CRC screening, is the methylation of the septin 9 (SEPT9) gene [259]. A search was also conducted for similar epigenetic biomarkers among the NP and Ntt genes. Therefore, e.g., expression of NT and NmN expressed in fetal colon, is reexpressed in $\sim 25 \%$ of colon cancers. Differential expression of both these genes was also described in vitro-positive in human colon cancer KM12C cell line and negative in KM20, which was associated with epigenetic changes. Gene silencing in KM20 cells concerns methylation of the CpG sites in a distal consensus AP-1 site in the NT and NmN promoter. In turn, NT and NmN gene expression in KM12C was associated with demethylation of the $\mathrm{CpG}$ sites [253]. Methylation of the NTSR1 promoter in some human CRC cells (KM12c, Caco2 and DLD1) and NTSR2 in all six CRC cell lines (KM12c, Caco2, DLD1, HT-29, HCT116 and SW480) was also noted [157]. The NTSR1 gene is also often methylated in CRC in vivo, with the higher level of methylation occurring in laterally growing, large, non-invasive tumors, which is associated with better prognosis [260]. Other studies suggest that methylation-associated silencing of NTSR1 is inversely correlated with invasiveness of CRC, and that a low level of methylation activates NTSR1 and is responsible for malignant potential of CRC [257].

Studies of the SP precursor, TAC1, showed that high methylation levels of these markers in serum at 6-month follow-up, and SEPT9 at 1-year follow-up, were independent predictors for tumor recurrence and unfavorable CSS [261]. Furthermore, methylation inhibited the expression of the NTRK3 gene, observed in $60 \%$ of colon adenomas, and $67 \%$ of colon adenocarcinomas. Loss of these genes' expression was associated with neoplastic transformation in vivo and in vitro [179].

Genetic/epigenetic changes also lead to activation of another potential proto-oncogene, TrKC. A decrease in TrKC expression was observed in a major portion of human CRCs. It was demonstrated that $\operatorname{TrKC}$ silencing by promoter methylation can limit tumor cell death. Additionally, the existence of two different tumor-associated TrKC mutants was proven in sporadic CRC. One of them is responsible for a gain-of-oncogenic function, while the other causes a loss of pro-apoptotic function, negating the tumor-suppressive effect of $\operatorname{TrKC}$ [178].

Other CRC-associated hypermethylation events, which significantly differentiated CRC and non-neoplastic tissue, as well as adenomas versus control, affected the GLP1R [254]. Studying the 
methylation levels of NPY, proenkephalin (PENK) and Wnt inhibitor factor 1 (WIF1), a potential diagnostic value of the combination of these three markers was proven in CRC [255]. In a study by Mitchell et al., the NPY gene was among the 7 others methylated in $>50 \%$ of CRC samples, compared with a low level of methylation in non-neoplastic colorectal tissue [256].

Identification of genes prognostic for CRC with the use of bioinformatic methods showed that low expression of 4 out of 10 of them, including GCG, is associated with an unfavorable prognosis [262]. Similarly, recent studies confirmed that GCG is among the top five downregulated genes in CRC $[263,264]$. However, this gene is not significantly associated with distant metastases (including LM).

Other studied epigenetic alterations concern ET-2 and ET-3. It was proven that epigenetic inactivation through hypermethylation of EDN2 and EDN3 is common in both rat and human colon cancers [110].

The candidate methylation targets in pCRC included SM (88\%) and the TAC1 (47\%) genes. The degree of methylation was, in both cases, associated with a decrease in mRNA production. The intensity of methylation in the case of TAC1 was higher in Dukes A/B than C/D. Hence, it cannot be associated with tumor progression (including LM). Significantly higher methylation of the SM was observed in low-level microsatellite stability (MSI-L) than non-MSI-L CRC [265]. In later publications on the SM gene, methylation status analyses showed a significantly higher level of promoter hypermethylation in CRC than in healthy young individuals, which can be linked to decreased SM production in CRC and uncontrolled cellular proliferation [221]. A significant correlation was found between serum methylation levels of $S M(m S M)$ and CSS, which allowed to indicate mSM as an independent predictor for poor CSS. Patients with high serum $\mathrm{mSM}$ were noted to have a higher risk for cancer-specific death ( $\mathrm{HR}=1.96,95 \% \mathrm{CI}$ : 1.06-3.62) [266]. The molecular mechanisms of SM gene promoter methylation in CRC development and progression (including distant metastasis) are unknown. Common and significant DNA methylation was also observed in three other genes, among them, sst2, in CRC tissues compared to adjacent normal tissues [258].

It was also reported that hypomethylation of genes, e.g., ACE, might play a prognostic role in CRC. This process is important in enhancing of cell proliferation, colony formation, inhibition of apoptosis and is related to CRC prognosis [244].

Furthermore, regarding the CRHR2 gene, a recent study indicates higher levels of hypermethylation of the gene in patients with $\mathrm{z}$ colitis-associated CRC versus non-tumorous mucosa, which could be used in screening, prognostics, as well as evaluation of therapy outcomes in patients with UC-associated CRC [267]. These studies could also determine that hypermethylation of CRHR2 may be responsible (similarly as in the case of SM) for lowered tissue expression of this protein [96], but also cell spreading, being a high metastasis risk factor in CRC [98].

\section{Targeting NP/NP-R System in CRC Liver Metastasis Molecular Therapy}

Based on the knowledge of NPs/NP-Rs, attempts were made to introduce several drugs for patients with advanced stages of CRC, such as the label phase I/II study with G17-DT (Gastrimmune), with no observed tumor regression [268]. Falciani et al. applied the tetra-branched NT armed with 5 -fluorouridine (5-FdU) and showed a 50\% reduction in tumor growth as compared to animals treated with placebo [269]. In in vitro conditions, superior drug internalization of DOPC-NT ${ }_{4} \mathrm{Lys}_{2}\left(\mathrm{C}_{18}\right)_{2}$ liposomes with NT8-13 fragments and containing Doxorubicin (peptide-functionalized liposomes) was proven over the "pure" DOPC liposomes [270]. When it comes to NTSR1, the use of radioligand therapy with NTSR1-targeting agent, ${ }^{177} \mathrm{Lu}-3 \mathrm{BP}-227$, inhibited tumor growth and decreased its volume by $55-88 \%$ [271]. Effectiveness of VIP hybrid antagonist neurotensin(6-11)VIP(7-28) was also proven, both in vitro and in an animal model (rat), in inhibition of tumor growth and decrease of its volume or staging [272]. Based on the knowledge about BBS/GRP, using an antagonist of these peptides, RC-3940-II, the volume of HT-29, HCT-116 and HCT-15 tumors xenografted into athymic nude 
mice decreased by $25 \%$ to $67 \%$. A better effect was obtained in combined therapy with RC-3940-II, 5-Fluorouracil (5-FU) and irinotecan [273].

If $\mathrm{LM}$ arises during the progression of $\mathrm{CRC}$, a standard procedure dictates liver resection $[14,16]$. Proper and rapid regeneration of the liver after surgical LM removal has importance equal to the initial outcome of surgery [274]. Apart from hepatectomy, a combination of chemotherapy and targeted drugs, e.g., anti-VEGF and anti-EGFR monoclonal antibodies, are also applied [14]. A search continues for other forms of LM therapy, e.g., thermal ablation with hepatectomy, which could lower patient mortality and help to avoid two-stage hepatectomy [275].

In the context of this review, there are also attempts to apply the knowledge about the NP/NP-R system in the development of LM therapy. As an example, inhibition of the RAS system was tested as a therapeutic approach $[225,274]$. A mouse model of partial hepatectomy showed that early liver regeneration (LR) is promoted by captopril (ACE inhibitor) via an increased number of HSCs and MMP9 levels. The results of this study could be valuable in ensuring enough liver regeneration and prevention of tumor recurrence after hepatectomy [274]. Research by Wen et al., conducted on an orthotopic murine model of LM, showed varying effects of RAS component action on the number of KCs in the liver, possibly leading to in LM progression. The use of captopril and ANG-(1-7) increased the numbers of KCs in the liver (but not in the metastatic tumor), with the former reducing LM growth [225].

Of patients with different models of liver metastatic CRC, therapeutic approaches using neuropeptides (or their agonists/antagonists) were tested. However, their number was limited, including (chronologically): Sst2 [276], Gal, serotonin and octreotide [277], RAS [225,278,279] and NPY [280] (Table 3). Most of the used therapies inhibited tumor growth and liver metastasis formation. Among the treatments based on the knowledge that many NPs can act as growth factors or oncogenes, there are currently no drugs qualified for clinical trials in the context of CRC. However, some NPs, e.g., NPY methylated (mNPY) ctDNA, might serve a role of universal and easily applicable biomarkers in CRC patients treated with regorafenib. A high baseline level of mNPY ctDNA correlated with shorter patient survival, with the results potentially helping with treatment monitoring [280].

To prevent LM, a search is underway for inhibitors of its different stages, including CRC cell proliferation with NP-R participation using, for example, miRNAs. It was proven in in vitro and in vivo conditions that miR-148b inhibits cell proliferation and carcinogenesis via downregulation of the CCK2R gene on a translational level [281]. In studies on HT-29-bearing mice, significant inhibition of tumor growth by Nts dopamine was also observed, but only in combination with 5-FU. While dopamine did not exhibit a direct effect on tumor growth, it inhibited angiogenesis by decreasing TEC proliferation via VEGF-R2, MAPK and FAK kinase phosphorylation [282]. Polydopamine nanoparticles are also a promising immunotherapy candidate. Applied in tumor-bearing mice, they delayed tumor progression due to a sufficient amount of cytotoxic T lymphocytes (CTLs) and M1-type TAMs as well as the deficient number of immunosuppression-related cells in the tumor tissues [283]. Gao et al. demonstrated that CCKR-targeted immunotoxin (rCCK8PE38) also has potential as a new immunotherapy agent, decreasing tumor size in nude mice with HCT-8 tumor xenografts, as well as acting cytotoxically in two CRC cell lines [284]. 
Table 3. Neuropeptides (NPs) and their receptors (NP-Rs) as potential targets and/or biomarkers during the treatment of CRC liver metastases.

\begin{tabular}{|c|c|c|c|c|}
\hline NPs/NP-R & Model of Research & Type of Treatment & Therapeutical Effects & Ref. \\
\hline SM receptor (SSR, Sst) & $\begin{array}{l}\text { SSR (Sst2)-transfected CC531 } \\
\text { CRC cells in a rat LM model } \\
\text { (CC2B LM) }\end{array}$ & $\begin{array}{l}\text { PRRT; } 185 \text { or } 370 \mathrm{MBq}(177 \\
\text { Lu-DOTA0, Tyr3) octreotate }\end{array}$ & $\begin{array}{l}\text { significant antitumor response in rats with } \\
\text { CC2B LM (SSR+) versus controls }\end{array}$ & [276] \\
\hline $\begin{array}{l}\text { SM analog (octreotide) } \\
\text { galanin, serotonin }\end{array}$ & $\begin{array}{l}\text { SW } 620 \text { CRC cells, nude } \\
\text { (C57BL/6JBom-nu) mice }\end{array}$ & $\begin{array}{l}\text { octreotide, galanin and } \\
\text { serotonin }\end{array}$ & $\begin{array}{l}\downarrow \text { incidence of metastases to the peritoneal } \\
\text { cavity in the treated animals ((but NS); } \uparrow \\
\text { LM and to the intra-abdominal lymph } \\
\text { nodes in controls; } \downarrow \text { tumor volume, wet } \\
\text { weight, proliferation index and number of } \\
\text { tumor blood vessels in the treated animals }\end{array}$ & [277] \\
\hline \multirow[t]{3}{*}{ RAS } & $\begin{array}{c}\text { mouse CRC cells (MoCR); } \\
\text { dimethylhydrazine-induced } \\
\text { CRC in a CBA mouse with LM }\end{array}$ & $\begin{array}{l}\text { rbesartan (AT1R blocker), } \\
\text { captopril (ACE blocker), } \\
\text { CGP42112A (AT2R agonist), } \\
\text { and/or ANG-(1-7) }\end{array}$ & $\begin{array}{c}\text { failed to show any benefit of combined } \\
\text { targeting of the RAS }\end{array}$ & [278] \\
\hline & $\begin{array}{l}\text { diabetic mouse model, LM of } \\
\text { CT26 mouse CRC cells }\end{array}$ & $\begin{array}{l}\text { anti-ANG treatment with a } \\
\text { chymase inhibitor, a renin } \\
\text { inhibitor, and an ANG II } \\
\text { receptor blocker }\end{array}$ & $\begin{array}{l}\text { concurrent hypoglycemic and anti-ANG } \\
\text { treatments showed a synergistic inhibitory } \\
\text { effect on CT26 cell liver metastasis }\end{array}$ & [279] \\
\hline & $\begin{array}{l}\text { orthotopic murine model of } \\
\text { CRC LM }\end{array}$ & ANG II, ANG-(1-7), captopril & $\begin{array}{l}\uparrow \mathrm{KC} \text { numbers in the liver but not tumor; } \\
\text { captopril reduced growth of LM }\end{array}$ & [225] \\
\hline NPY & $\begin{array}{l}\mathrm{N}=100 \text { of metastatic CRC } \\
\text { patients; ctDNA with mNPY }\end{array}$ & $\begin{array}{l}\text { Regorafenib as last-line } \\
\text { treatment }\end{array}$ & $\#, \uparrow$ baseline level of ctDNA of mNPY & [280] \\
\hline
\end{tabular}

Legend: ANG—angiotensin; ACE—ANG converting enzyme; AT1R/2R—ANG II type 1/2 receptor; CRC—colorectal cancer; ct—circulating tumor; KC—Kupffer cells; LM-liver metastases; m-methylated; $n$ —numer of patients; NPY—Neuropeptide Y; NS—non significant; PRRT—Peptide Receptor Radionuclide Therapy; RAS—Renin Angiotensin System; SM—somatostatin; Ref.—number of references; $\uparrow / \downarrow$-significantly increased/decreased; \#—significant correlation with poor prognosis (Overall Survival). 


\section{The Main Headlines of the Review}

In vitro and/or animal model studies on the mechanisms of Nts and NPs/Ntt action, confirm the participation of these molecule systems (mainly their overexpression) in main stages in CRC liver metastasis.

In the process of increased cell proliferation, migration and invasion (first step of metastasis), the most commonly described signaling pathways, activated by the studied neuroactive molecule systems, are Axin1/ $\beta$-catenin/MMP7 (serotonin), cAMP-Rap1/Ras-B-Raf-ERK (VIP), EGFRs/PI3K/ERK/AKT/mTOR (ACh, serotonin, G17-Gly, GLP2), FAK (gastrin, progastrin, GRP), IP3/Ca ${ }^{+2} /$ PKC/MAPKs (GCG, NT/NTSR1, neurotrophins), MMPs/EGFR/MAPKs (PI3K/AKT) (ACh, ET-1, NT/NTSR1), PI3K/ $\beta$-catenin/TCF4 (G17, NPY), Rho-GTPases and non-receptor tyrosine kinase (NT/NTSR1), as well as Wnt signaling (SP). CRH/CRHR2 and SM/Sst3/5 systems exhibit inhibitory effects on the proliferation of CRC cells. Both in the cases of SM and CRHR2, epigenetic changes causing lowered production of these components were described in CRC patients, resulting in the ability for increased cell spread and appearance of distant metastases (including LM).

During cell-extracellular matrix loss of adhesion, the participation of, for example, ACh, CRHR2, G17-Gly, NTSR3 (sortilin) and TrKB, was confirmed. The main signaling pathways described in this step are AKT (TrKB), FAK/Src-PI3K/Ca ${ }^{+2}$ (NTSR3) and Src/ERK (CRHR2). The EMT program is induced by the action of, for example, AT2R, GPR56 and TrKB. During angiogenesis, mostly promoting (e.g., AT1R, CRHR1, G17, GlyG17, NT, progastrin, TrKB), but also inhibiting effects (e.g., SM) were described, as well as a dual role of NP/NP-Rs on the process (NPY).

In vivo studies confirm the production of numerous $\mathrm{Nts} / \mathrm{NP} / \mathrm{Ntt}$ and their receptors in neural structures (neurons, nerve fibers) or EECs, tumor microenvironment cells (TECs, TAMs, myofibroblasts), as well as in pCRC and metastatic cells. It is worth noting that peptide expression concerns different tumor cell populations, while the presence of their receptors is mostly characteristic for cancer cells. Liver metastasis presence was positively correlated with tissue expression/overexpression of many NP/NP-Rs (e.g., AT1R, BDNF, BDNF/TrKB, ET-1, gastrin, progastrin, SP/NK-1R system, TrKB and TrKC), as well as a lack or lower expression of some of them (e.g., AT2R, CRHR2, GRP/GRPR, Sst3 and Sst5).

Studies on the role of the serum NP/NP-R concentration were mostly conducted in recent years and indicate a diagnostic-prognostic role of these peptides. Higher levels of Nts/NPs were noted in pCRC versus control (serotonin, ET-1, big ET-1, galanin, G17, GLP1/GLP2, NT, PYY and SP), as well as in metastatic CRC than pCRC (gastrin, VIP), metastatic CRC versus control (ET-1) or in CRC compared to other types of GIT cancer (pancreatic, gastric cancers) (NT, VIP).

While there is a lack of description of liver metastasis typical mutations/epigenetic alterations concerning Nts/NPs/Ntt, a continuation of studies is essential in the elucidation of the mechanism of not only the development, but also metastasis, involving aberrant methylated DNA, or the discovery of a more universal epigenetic profile of CRC and LM.

\section{Conclusions}

1. Studies on the role of NP/NP-Rs in the promotion of the invasion-metastasis cascade in CRC, show the complexity of brain-large intestine-tumor interactions, caused by their different forms of release to the extracellular environment (endocrine, autocrine, paracrine and neurocrine). More research is needed to understand the exact mechanisms of neuronal-tumor cells communication.

2. Many steps of CRC promotion, progression and liver metastasis are connected to the activity of pro-inflammatory (CRHR1, NPY, NT), anti-inflammatory (CGRP, CRHR2, VIP) or dual role (SP) NPs, regulation of the local immunological profile (CRH/CRHRs), dysfunctions of the protective/enterotrophic role of NPs on epithelial cells (NT/NTSR system), structural-functional changes in ENS innervation of the large intestine in CRC (including PNI), or other tumor-promoting factors (bacterial GIT infections, such as H. pylori).

3. The knowledge on the mechanisms regulating tumor growth and different steps of metastasis, as well as effects of the action of a numerous group of $\mathrm{Nts} / \mathrm{NPs} / \mathrm{Ntt}$ as growth factors, 
have implications for future therapeutic strategies. For obtaining the best treatment outcomes, it is important to use signaling pathways common for many NPs, as well as the development of broad-spectrum antagonists.

Author Contributions: Both authors worked on the information compilation, analysis and manuscript writing equally. All authors have read and agreed to the published version of the manuscript.

Funding: This research received no external funding.

Conflicts of Interest: The authors declare no conflict of interest.

\section{Abbreviations}

aa

APUD

CI

ACE

AKT

AT1R/2R

BBS

CCK-BR (CCK2R)

c-Met

$\mathrm{CN}$

CRC

CRHR1/CRHR2

CSS

DFS

ECs

ECM

EECs

EGF/R

EMT

ERK1/2

ET/AR/BR

FAK

GC

GCG

GLP1/2/R

GPCR

GPR56

GRP/R

HB-EGF

HR

HSCs

5HT3/4 -5HT

IL

LM

MAPK

MMP2, -7, -9

NET

NF- KB

NK-1R

$\mathrm{NmB} / \mathrm{R}$ amino acids

Amine Precursor Uptake and Decarboxylation

Confidence Interval

Angiotensin I Converting Enzyme

Serine-threonine Protein Kinase (now called AKT1)

Angiotensin 1/2 receptors

Bombesin

Cholecystokinin-B/gastrin Receptor

Tyrosine-protein Kinase Met or Hepatocyte Growth Factor Receptor

Cranial Nerve

Colorectal Carcinoma

Corticotropin-releasing Hormone (Factor) Receptors

Cancer-Specific Survival

Disease-free Survival

Endothelial Cells

Extracellular Matrix

Enteroendocrine cells

Epidermal Growth Factor/Receptor

Epithelial-mesenchymal Transition

Extracellular Signal-regulated Kinase 1/2

Endothelin/Receptor A/B

Focal Adhesion Kinase

Gastric Cancer

Glucagon

Glucagon-Like Peptides/Receptor

G Protein-coupled Receptors

G Protein-coupled Receptor 56

Gastrin-Releasing Peptide/Receptor

Heparin-binding EGF-like Growth Factor

Hazard Ratio

Hepatic Stellate Cells

Serotonin Receptors

Interleukin

Liver Metastasis

Mitogen-activated Protein Kinase (originally called ERK)

Matrix mmetalloproteinase 2, -7, -9

Neuroendocrine Tumor

Nuclear factor kappa-light-chain-enhancer of activated B cells

Neurokinin1 Receptor

Neuromedin B/Receptor 


$\begin{array}{ll}\text { NT/NTSR1 } & \text { Neurotensin/NT Receptor } 1 \\ \text { OR } & \text { Odds Ratio } \\ \text { OS } & \text { Overall Survival } \\ \text { PFS } & \text { Progression-free Survival } \\ \text { PI3 } & \text { Phosphatidylinositol 3-kinase } \\ \text { PKA, B (AKT), C } & \text { Protein Kinase A, B (AKT), C } \\ \text { PG } & \text { Progastrin } \\ \text { PP } & \text { Pancreatic Peptide } \\ \text { PYY } & \text { Peptide YY } \\ \text { RFS } & \text { Recurrence-free Survival } \\ \text { SM } & \text { Somatostatin } \\ \text { SP } & \text { Substance P } \\ \text { Sst } & \text { Somatostatin Receptors } \\ \text { TAC1 } & \text { Tachykinin-1 } \\ \text { TAMs } & \text { Tumor-Associated Macrophages } \\ \text { TECs } & \text { Tumor Endothelial Cells } \\ \text { TGF- } \alpha, \beta & \text { Transforming Growth Factor } \alpha, \beta \\ \text { TNF- } \alpha & \text { Tumor Necrosis Factor } \alpha \\ \text { TNM } & \text { T-primary tumor, N-regional lymph nodes, M-distant metastasis } \\ \text { TrK } & \text { Tropomyosin-related Kinase } \\ \text { VEGF } & \text { Vascular Endothelial Growth Factor } \\ \text { VIP } & \text { Vasoactive Intestinal Peptide } \\ \text { VPAC1 } & \text { VIP Receptor 1 }\end{array}$

\section{References}

1. Bray, F.; Ferlay, J.; Soerjomataram, I.; Siegel, R.L.; Torre, L.A.; Jemal, A. Global cancer statistics 2018: GLOBOCAN estimates of incidence and mortality worldwide for 36 cancers in 185 countries. CA Cancer J. Clin. 2018, 68, 394-424. [CrossRef]

2. Ferlay, J.; Colombet, M.; Soerjomataram, I.; Mathers, C.; Parkin, D.M.; Piñeros, M.; Znaor, A.; Bray, F. Estimating the global cancer incidence and mortality in 2018: GLOBOCAN sources and methods. Int. J. Cancer 2019, 144, 1941-1953. [CrossRef]

3. Ferlay, J.; Colombet, M.; Soerjomataram, I.; Dyba, T.; Randi, G.; Bettio, M.; Gavin, A.; Visser, O.; Bray, F. Cancer incidence and mortality patterns in Europe: Estimates for 40 countries and 25 major cancers in 2018. Eur. J. Cancer 2018, 103, 356-387. [CrossRef]

4. Engstrand, J.; Nilsson, H.; Strömberg, C.; Jonas, E.; Freedman, J. Colorectal cancer liver metastases-A population-based study on incidence, management and survival. BMC Cancer 2018, 18, 78. [CrossRef]

5. Engstrand, J.; Strömberg, C.; Nilsson, H.; Freedman, J.; Jonas, E. Synchronous and metachronous liver metastases in patients with colorectal cancer-towards a clinically relevant definition. World J. Surg. Oncol. 2019, 17, 228. [CrossRef]

6. Xu, F.; Tang, B.; Jin, T.Q.; Dai, C.L. Current status of surgical treatment of colorectal liver metastases. World J. Clin. Cases 2018, 6, 716-734. [CrossRef]

7. De Ridder, J.; de Wilt, J.H.; Simmer, F.; Overbeek, L.; Lemmens, V.; Nagtegaal, I. Incidence and origin of histologically confirmed liver metastases: An explorative case-study of 23,154 patients. Oncotarget 2016, 7, 55368-55376. [CrossRef] [PubMed]

8. Milette, S.; Sicklick, J.K.; Lowy, A.M.; Brodt, P. Molecular pathways: Targeting the microenvironment of liver metastases. Clin. Cancer Res. 2017, 23, 6390-6399. [CrossRef] [PubMed]

9. Valderrama-Treviño, A.; Barrera-Mera, B.; Ceballos-Villalva, J.C.; Montalvo-Javé, E.E. Hepatic Metastasis from colorectal cancer. Euroasian J. Hepatogastroenterol. 2017, 7, 166-175. [CrossRef] [PubMed]

10. Wang, J.; Li, S.; Liu, Y.; Zhang, C.; Li, H.; Lai, B. Metastatic patterns and survival outcomes in patients with stage IV colon cancer: A population-based analysis. Cancer Med. 2020, 9, 361-373. [CrossRef]

11. Jin, K.; Gao, W.; Lu, Y.; Lan, H.; Teng, L.; Cao, F. Mechanisms regulating colorectal cancer cell metastasis into liver (Review). Oncol. Lett. 2012, 3, 11-15. [CrossRef] [PubMed] 
12. Zhang, Y.; Davis, C.; Ryan, J.; Janney, C.; Peña, M.M. Development and characterization of a reliable mouse model of colorectal cancer metastasis to the liver. Clin. Exp. Metastasis 2013, 30, 903-918. [CrossRef] [PubMed]

13. Sadahiro, S.; Suzuki, T.; Tanaka, A.; Okada, K.; Kamata, H. Hematogenous metastatic patterns of curatively resected colon cancer were different from those of stage IV and autopsy Cases. Jpn. J. Clin. Oncol. 2013, 43, 444-447. [CrossRef]

14. De Greef, K.; Rolfo, C.; Russo, A.; Chapelle, T.; Bronte, G.; Passiglia, F.; Coelho, A.; Papadimitriou, K.; Peeters, M. Multisciplinary management of patients with liver metastasis from colorectal cancer. World J. Gastroenterol. 2016, 22, 7215-7225. [CrossRef] [PubMed]

15. Ji, B.; Feng, Y.; Sun, Y.; Ji, D.; Qian, W.; Zhang, Z.; Wang, Q.; Zhang, Y.; Zhang, C.; Sun, Y. GPR56 promotes proliferation of colorectal cancer cells and enhances metastasis via epithelial-mesenchymal transition through PI3K/AKT signaling activation. Oncol. Rep. 2018, 40, 1885-1896. [CrossRef] [PubMed]

16. Dörr, N.M.; Bartels, M.; Morgul, M.H. Current treatment of colorectal liver metastasis as a chronic disease. Anticancer Res. 2020, 40, 1-7. [CrossRef]

17. Xu, X.T.; Xu, B.; Song, Q.B.; Zeng, H. The role of neural-related factors in the metastasis of the gastrointestinal cancer. J. Cancer Res. Ther. 2013, 9, S123-S128. [CrossRef]

18. Kuol, N.; Stojanovska, L.; Apostolopoulos, V.; Nurgali, K. Role of the nervous system in cancer metastasis. J. Exp. Clin. Cancer Res. 2018, 37, 5. [CrossRef]

19. Brodt, P. Role of the microenvironment in liver metastasis: From Pre- to Prometastatic Niches. Clin. Cancer Res. 2016, 22, 5971-5982. [CrossRef]

20. Williamson, T.; Sultanpuram, N.; Sendi, H. The role of liver microenvironment in hepatic metastasis. Clin. Transl. Med. 2019, 8, 21. [CrossRef]

21. Pretzsch, E.; Bösch, F.; Neumann, J.; Ganschow, P.; Bazhin, A.; Guba, M.; Werner, J.; Angele, M. Mechanisms of metastasis in colorectal cancer and metastatic organotropism: Hematogenous versus peritoneal spread. J. Oncol. 2019, 2019, 7407190. [CrossRef] [PubMed]

22. Teeuwssen, M.; Fodde, R. Cell heterogeneity and phenotypic plasticity in metastasis formation: The case of colon cancer. Cancers 2019, 11, 1368. [CrossRef] [PubMed]

23. Hugen, N.; van de Velde, C.J.; de Wilt, J.H.; Nagtegaal, I.D. Metastatic pattern in colorectal cancer is strongly influenced by histological subtype. Ann. Oncol. 2014, 25, 651-657. [CrossRef] [PubMed]

24. Shimomoto, T.; Ohmori, H.; Luo, Y.; Chihara, Y.; Denda, A.; Sasahira, T.; Tatsumoto, N.; Fujii, K.; Kuniyasu, H. Diabetes-associated angiotensin activation enhances liver metastasis of colon cancer. Clin. Exp. Metastasis. 2012, 29, 915-925. [CrossRef] [PubMed]

25. Wang, C.; Li, P.; Xuan, J.; Zhu, C.; Liu, J.; Shan, L.; Du, Q.; Ren, Y.; Ye, J. Cholesterol enhances colorectal cancer progression via ROS elevation and MAPK signaling pathway activation. Cell Physiol. Biochem. 2017, 42, 729-742. [CrossRef]

26. Mohr, A.M.; Gould, J.J.; Kubik, J.L.; Talmon, G.A.; Casey, C.A.; Thomas, P.; Tuma, D.J.; McVicker, B.L. Enhanced colorectal cancer metastases in the alcohol-injured liver. Clin. Exp. Metastasis 2017, 34, 171-184. [CrossRef] [PubMed]

27. Pathak, S.; Pandanaboyana, S.; Daniels, I.; Smart, N.; Prasad, K.R. Obesity and colorectal liver metastases: Mechanisms and management. Surg. Oncol. 2016, 25, 246-251. [CrossRef]

28. Albo, D.; Akay, C.L.; Marshall, C.L.; Wilks, J.A.; Verstovsek, G.; Liu, H.; Agarwal, N.; Berger, D.H.; Ayala, G.E. Neurogenesis in colorectal cancer is a marker of aggressive tumor behavior and poor outcomes. Cancer 2011, 117, 4834-4845. [CrossRef]

29. Yang, Y.; Huang, X.; Sun, J.; Gao, P.; Song, Y.; Chen, X.; Zhao, J.; Wang, Z. Prognostic value of perineural invasion in colorectal cancer: A meta-analysis. J. Gastrointest. Surg. 2015, 19, 1113-1122. [CrossRef]

30. Wang, X.; Chen, X.; Zhou, H.; Qian, Y.; Han, N.; Tian, X.; Pan, L.; Li, Y. The long noncoding RNA, LINC01555, promotes invasion and metastasis of colorectal cancer by activating the neuropeptide, Neuromedin U. Med. Sci. Monit. 2019, 25, 4014-4024. [CrossRef]

31. De Wied, D. Peptide hormones and neuropeptides: Birds of a feather. Trends Neurosci. 2000, $23,113$. [CrossRef]

32. Hillebrand, J.J.; de Wied, D.; Adan, R.A. Neuropeptides, food intake and body weight regulation: A hypothalamic focus. Peptides 2002, 23, 2283-2306. [CrossRef] 
33. Burbach, J.P. Neuropeptides from concept to online database www.neuropeptides.nl. Eur. J. Pharmacol. 2010, 626, 27-48. [CrossRef] [PubMed]

34. Burbach, J.P. What are neuropeptides? Methods Mol. Biol. 2011, 789, 1-36. [CrossRef]

35. Hallberg, M. Neuropeptides: Metabolism to bioactive fragments and the pharmacology of their receptors. Med. Res. Rev. 2015, 3, 464-519. [CrossRef]

36. Hökfelt, T.; Bartfai, T.; Bloom, F. Neuropeptides: Opportunities for drug discovery. Lancet Neurol. 2003, 8, 463-472. [CrossRef]

37. Kastin, A.J. What is a neuropeptide? Trends Neurosci. 2000, 23, 113-114. [CrossRef]

38. Heasley, L.E. Autocrine and paracrine signaling through neuropeptide receptors in human Cancer. Oncogene 2001, 20, 1563-1569. [CrossRef]

39. Hoyer, D.; Bartfai, T. Neuropeptides and neuropeptide receptors: Drug targets, and peptide and non-peptide ligands: A tribute to Prof. Dieter Seebach. Chem. Biodivers 2012, 9, 2367-2387. [CrossRef]

40. Moody, T.W.; Ramos-Alvarez, I.; Jensen, R.T. Neuropeptide G protein-coupled receptors as oncotargets. Front. Endocrinol. 2018, 9, 345. [CrossRef]

41. Nässel, D.R.; Zandawala, M. Recent advances in neuropeptide signaling in Drosophila, from genes to physiology and behavior. Prog. Neurobiol. 2019, 179, 101607. [CrossRef] [PubMed]

42. Neuropeptides Family. Available online: https://www.neuropeptides.nl (accessed on 1 April 2020).

43. Romanova, E.V.; Sweedler, J.V. Peptidomics for the discovery and characterization of neuropeptides and hormones. Trends Pharmacol. Sci. 2015, 36, 579-586. [CrossRef] [PubMed]

44. Gross, K.J.; Pothoulakis, C. Role of neuropeptides in inflammatory bowel disease. Inflamm. Bowel Dis. 2007, 13, 918-932. [CrossRef] [PubMed]

45. Tang, B.; Yong, X.; Xie, R.; Li, Q.W.; Yang, S.M. Vasoactive intestinal peptide receptor-based imaging and treatment of tumors (review). Int. J. Oncol. 2014, 44, 1023-1031. [CrossRef]

46. Moody, T.W.; Nuche-Berenguer, B.; Jensen, R.T. Vasoactive intestinal peptide/pituitary adenylate cyclase activating polypeptide, and their receptors and Cancer. Curr. Opin. Endocrinol. Diabetes Obes. 2016, 23, $38-47$. [CrossRef]

47. Westwood, D.A.; Patel, O.; Christophi, C.; Shulkes, A.; Baldwin, G.S. Progastrin: A potential predictive marker of liver metastasis in colorectal Cancer. Int. J. Colorectal Dis. 2017, 32, 1061-1064. [CrossRef]

48. Kim, J.Y.; Kim, K.S.; Kim, K.J.; Park, I.J.; Lee, J.L.; Myung, S.J.; Park, Y.; Park, Y.S.; Yu, C.S.; Kim, J.C.; et al. Non-L-cell immunophenotype and large tumor size in rectal neuroendocrine tumors are associated with aggressive clinical behavior and worse prognosis. Am. J. Surg. Pathol. 2015, 39, 632-643. [CrossRef]

49. Kontovounisios, C.; Qiu, S.; Rasheed, S.; Darzi, A.; Tekkis, P. The role of neurotensin as a novel biomarker in the endoscopic screening of high-risk population for developing colorectal neoplasia. Updates Surg. 2017, 69, 397-402. [CrossRef]

50. Furness, J.B.; Callaghan, B.P.; Rivera, L.R.; Cho, H.J. The enteric nervous system and gastrointestinal innervation: Integrated local and central control. Adv. Exp. Med. Biol. 2014, 817, 39-71. [CrossRef]

51. Fornai, M.; van den Wijngaard, R.M.; Antonioli, L.; Pellegrini, C.; Blandizzi, C.; de Jonge, W.J. Neuronal regulation of intestinal immune functions in health and disease. Neurogastroenterol. Motil. 2018, 30, e13406. [CrossRef]

52. Brinkman, D.J.; Ten Hove, A.S.; Vervoordeldonk, M.J.; Luyer, M.D.; de Jonge, W.J. Neuroimmune interactions in the gut and their significance for intestinal immunity. Cells 2019, 8, 670. [CrossRef] [PubMed]

53. Grider, J.R. Gastrin-releasing peptide is a modulatory neurotransmitter of the descending phase of the peristaltic reflex. Am. J. Physiol. Gastrointest. Liver Physiol. 2004, 287, G1109-G1115. [CrossRef] [PubMed]

54. Monstein, H.J.; Grahn, N.; Truedsson, M.; Ohlsson, B. Progastrin-releasing peptide and gastrin-releasing peptide receptor mRNA expression in non-tumor tissues of the human gastrointestinal tract. World J. Gastroenterol. 2006, 12, 2574-2578. [CrossRef] [PubMed]

55. Bulut, K.; Felderbauer, P.; Deters, S.; Hoeck, K.; Schmidt-Choudhury, A.; Schmidt, W.E.; Hoffmann, P. Sensory neuropeptides and epithelial cell restitution: The relevance of SP- and CGRP-stimulated mast cells. Int. J. Colorectal Dis. 2008, 23, 535-541. [CrossRef] [PubMed]

56. Gonkowski, S.; Rytel, L. Somatostatin as an Active Substance in the Mammalian Enteric Nervous System. Int. J. Mol. Sci. 2019, 20, 4461. [CrossRef] [PubMed]

57. Azriel, Y.; Liu, L.; Burcher, E. Complex actions of neurotensin in ascending and sigmoid colonic muscle: Involvement of enteric mediators. Eur. J. Pharmacol. 2010, 644, 195-202. [CrossRef] 
58. Mustain, W.C.; Rychahou, P.G.; Evers, B.M. The role of neurotensin in physiologic and pathologic processes. Curr. Opin. Endocrinol. Diabetes Obes. 2011, 18, 75-82. [CrossRef]

59. Furness, J.B. Integrated neural and endocrine control of gastrointestinal function. Adv. Exp. Med. Biol. 2016, 891, 159-173. [CrossRef]

60. Gunawardene, A.R.; Corfe, B.M.; Staton, C.A. Classification and functions of enteroendocrine cells of the lower gastrointestinal tract. Int. J. Exp. Pathol. 2011, 92, 219-231. [CrossRef]

61. Billing, L.J.; Larraufie, P.; Lewis, J.; Leiter, A.; Li, J.; Lam, B.; Yeo, G.S.; Goldspink, D.A.; Kay, R.G.; Gribble, F.M.; et al. Single cell transcriptomic profiling of large intestinal enteroendocrine cells in mice-Identification of selective stimuli for insulin-like peptide- 5 and glucagon-like peptide-1 co-expressing cells. Mol. Metab. 2019, 29, 158-169. [CrossRef]

62. Li, S.; Sun, Y.; Gao, D. Role of the nervous system in cancer metastasis. Oncol. Lett. 2013, 5, 1101-1111. [CrossRef] [PubMed]

63. Saloman, J.L.; Albers, K.M.; Rhim, A.D.; Davis, B.M. Can stopping nerves, stop cancer? Trends Neurosci. 2016, 39, 880-889. [CrossRef] [PubMed]

64. Ashraf, S.; Crowe, R.; Loizidou, M.C.; Turmaine, M.; Taylor, I.; Burnstock, G. The absence of autonomic perivascular nerves in human colorectal liver metastases. Br. J. Cancer 1996, 73, 349-359. [CrossRef] [PubMed]

65. Godlewski, J.; Kaleczyc, J. Somatostatin, substance P and calcitonin gene-related peptide-positive intramural nerve structures of the human large intestine affected by carcinoma. Folia Histochem. Cytobiol. 2010, 48, 475-483. [CrossRef] [PubMed]

66. Godlewski, J.; Łakomy, I.M. Changes in vasoactive intestinal peptide, pituitary adenylate cyclase-activating polypeptide and neuropeptide Y-ergic structures of the enteric nervous system in the carcinoma of the human large intestine. Folia Histochem. Cytobiol. 2010, 48, 208-216. [CrossRef]

67. Kwiatkowski, P.; Godlewski, J.; Kieżun, J.; Kraziński, B.E.; Kmieć, Z. Colorectal cancer patients exhibit increased levels of galanin in serum and colon tissues. Oncol. Lett. 2016, 12, 3323-3329. [CrossRef]

68. Godlewski, J.; Pidsudko, Z. Characteristic of galaninergic components of the enteric nervous system in the cancer invasion of human large intestine. Ann. Anat. 2012, 194, 368-372. [CrossRef]

69. Zauszkiewicz-Pawlak, A.; Godlewski, J.; Kwiatkowski, P.; Kmiec, Z. Ultrastructural characteristics of myenteric plexus in patients with colorectal Cancer. Folia Histochem. Cytobiol. 2017, 55, 6-10. [CrossRef]

70. Chen, S.H.; Zhang, B.Y.; Zhou, B.; Zhu, C.Z.; Sun, L.Q.; Feng, Y.J. Perineural invasion of cancer: A complex crosstalk between cells and molecules in the perineural niche. Am. J. Cancer Res. 2019, 9, 1-21.

71. Liebig, C.; Ayala, G.; Wilks, J.A.; Berger, D.H.; Albo, D. Perineural invasion in cancer: A review of the literature. Cancer 2009, 115, 3379-3391. [CrossRef]

72. Liebig, C.; Ayala, G.; Wilks, J.; Verstovsek, G.; Liu, H.; Agarwal, N.; Berger, D.H.; Albo, D. Perineural invasion is an independent predictor of outcome in colorectal cancer. J. Clin. Oncol. 2009, 27, 5131-5137. [CrossRef]

73. Nozawa, H.; Hata, K.; Ushiku, T.; Kawai, K.; Tanaka, T.; Shuno, Y.; Nishikawa, T.; Sasaki, K.; Emoto, S.; Kaneko, M.; et al. Accelerated perineural invasion in colitis-associated cancer: A retrospective cohort study. Medicine 2019, 98, e17570. [CrossRef] [PubMed]

74. Zhou, Y.; Wang, H.; Gong, H.; Cao, M.; Zhang, G.; Wang, Y. Clinical significance of perineural invasion in stages II and III colorectal Cancer. Pathol. Res. Pract. 2015, 211, 839-844. [CrossRef]

75. Fujii, T.; Mashimo, M.; Moriwaki, Y.; Misawa, H.; Ono, S.; Horiguchi, K.; Kawashima, K. Expression and function of the cholinergic system in immune cells. Front. Immunol. 2017, 8, 1085. [CrossRef] [PubMed]

76. Davis, E.A.; Dailey, M.J. A direct effect of the autonomic nervous system on somatic stem cell proliferation? Am. J. Physiol. Regul. Integr. Comp. Physiol. 2019, 316, R1-R5. [CrossRef] [PubMed]

77. Merlos-Suárez, A.; Barriga, F.M.; Jung, P.; Iglesias, M.; Céspedes, M.V.; Rossell, D.; Sevillano, M.; Hernando-Momblona, X.; da Silva-Diz, V.; Muñoz, P.; et al. The intestinal stem cell signature identifies colorectal cancer stem cells and predicts disease relapse. Cell Stem Cell. 2011, 8, 511-524. [CrossRef]

78. Kim, E.R.; Chang, D.K. Colorectal cancer in inflammatory bowel disease: The risk, pathogenesis, prevention and diagnosis. World J. Gastroenterol. 2014, 20, 9872-9881. [CrossRef]

79. Larauche, M.; Kiank, C.; Tache, Y. Corticotropin releasing factor signaling in colon and ileum: Regulation by stress and pathophysiological implications. J. Physiol. Pharmacol. 2009, 60 (Suppl. 7), 33-46.

80. Konturek, P.C.; Brzozowski, T.; Konturek, S.J. Stress and the gut: Pathophysiology, clinical consequences, diagnostic approach and treatment options. J. Physiol. Pharmacol. 2011, 62, 591-599. 
81. Margolis, K.G.; Gershon, M.D. Neuropeptides and inflammatory bowel disease. Curr. Opin. Gastroenterol. 2009, 25, 503-511. [CrossRef]

82. Buckinx, R.; Adriaensen, D.; Nassauw, L.V.; Timmermans, J.P. Corticotrophin-releasing factor, related peptides, and receptors in the normal and inflamed gastrointestinal tract. Front. Neurosci. 2011, 5, 54. [CrossRef] [PubMed]

83. Sideri, A.; Bakirtzi, K.; Shih, D.Q.; Koon, H.W.; Fleshner, P.; Arsenescu, R.; Arsenescu, V.; Turner, J.R.; Karagiannides, I.; Pothoulakis, C. Substance P mediates pro-inflammatory cytokine release form mesenteric adipocytes in Inflammatory Bowel Disease patients. Cell Mol. Gastroenterol. Hepatol. 2015, 1, 420-432. [CrossRef] [PubMed]

84. Baritaki, S.; de Bree, E.; Chatzaki, E.; Pothoulakis, C. Chronic Stress, Inflammation, and colon cancer: A CRH system-driven molecular crosstalk. J. Clin. Med. 2019, 8, 1669. [CrossRef]

85. Castagliuolo, I.; Wang, C.C.; Valenick, L.; Pasha, A.; Nikulasson, S.; Carraway, R.E.; Pothoulakis, C. Neurotensin is a proinflammatory neuropeptide in colonic inflammation. J. Clin. Investig. 1999, 103, 843-849. [CrossRef]

86. Koon, H.W.; Zhao, D.; Zhan, Y.; Simeonidis, S.; Moyer, M.P.; Pothoulakis, C. Substance P-stimulated interleukin-8 expression in human colonic epithelial cells involves protein kinase Cdelta activation. J. Pharmacol. Exp. Ther. 2005, 314, 1393-1400. [CrossRef]

87. Zhao, D.; Zhan, Y.; Zeng, H.; Koon, H.W.; Moyer, M.P.; Pothoulakis, C. Neurotensin stimulates interleukin-8 expression through modulation of I kappa B alpha phosphorylation and p65 transcriptional activity: Involvement of protein kinase C alpha. Mol. Pharmacol. 2005, 67, 2025-2031. [CrossRef]

88. Zhao, D.; Pothoulakis, C. Effects of NT on gastrointestinal motility and secretion, and role in intestinal inflammation. Peptides 2006, 27, 2434-2444. [CrossRef]

89. Kalafatakis, K.; Triantafyllou, K. Contribution of neurotensin in the immune and neuroendocrine modulation of normal and abnormal enteric function. Regul. Pept. 2011, 170, 7-17. [CrossRef]

90. Zhao, D.; Zhan, Y.; Koon, H.W.; Zeng, H.; Keates, S.; Moyer, M.P.; Pothoulakis, C. Metalloproteinase-dependent transforming growth factor-alpha release mediates neurotensin-stimulated MAP kinase activation in human colonic epithelial cells. J. Biol. Chem. 2004, 279, 43547-43554. [CrossRef]

91. Bugni, J.M.; Rabadi, L.A.; Jubbal, K.; Karagiannides, I.; Lawson, G.; Pothoulakis, C. The neurotensin receptor-1 promotes tumor development in a sporadic but not an inflammation-associated mouse model of colon Cancer. Int. J. Cancer 2012, 130, 1798-1805. [CrossRef]

92. Bakirtzi, K.; Law, I.K.; Xue, X.; Iliopoulos, D.; Shah, Y.M.; Pothoulakis, C. Neurotensin promotes the development of colitis and intestinal angiogenesis via Hif- $1 \alpha-m i R-210$ signaling. J. Immunol. 2016, 196, 4311-4321. [CrossRef] [PubMed]

93. Karagiannides, I.; Pothoulakis, C. Neuropeptides, mesenteric fat, and intestinal inflammation. Ann. N. Y. Acad. Sci. 2008, 1144, 127-135. [CrossRef] [PubMed]

94. Zhao, D.; Bakirtzi, K.; Zhan, Y.; Zeng, H.; Koon, H.W.; Pothoulakis, C. Insulin-like growth factor-1 receptor transactivation modulates the inflammatory and proliferative responses of neurotensin in human colonic epithelial cells. J. Biol. Chem. 2011, 286, 6092-6099. [CrossRef]

95. Liu, S.; Zeng, Y.; Li, Y.; Guo, W.; Liu, J.; Ouyang, N. VPAC1 overexpression is associated with poor differentiation in colon Cancer. Tumour Biol. 2014, 35, 6397-6404. [CrossRef] [PubMed]

96. Rodriguez, J.A.; Huerta-Yepez, S.; Law, I.K.; Baay-Guzman, G.J.; Tirado-Rodriguez, B.; Hoffman, J.M.; Iliopoulos, D.; Hommes, D.W.; Verspaget, H.W.; Chang, L.; et al. Diminished expression of CRHR2 in human colon cancer promotes tumor growth and EMT via persistent IL-6/Stat3 signaling. Cell Mol. Gastroenterol. Hepatol. 2015, 1, 610-630. [CrossRef] [PubMed]

97. Fang, X.; Hong, Y.; Dai, L.; Qian, Y.; Zhu, C.; Wu, B.; Li, S. CRH promotes human colon cancer cell proliferation via IL-6/JAK2/STAT3 signaling pathway and VEGF-induced tumor angiogenesis. Mol. Carcinog. 2017, 56, 2434-2445. [CrossRef]

98. Pothoulakis, C.; Torre-Rojas, M.; Duran-Padilla, M.A.; Gevorkian, J.; Zoras, O.; Chrysos, E.; Chalkiadakis, G.; Baritaki, S. CRHR2/Ucn2 signaling is a novel regulator of miR-7/YY1/Fas circuitry contributing to reversal of colorectal cancer cell resistance to Fas-mediated apoptosis. Int. J. Cancer 2018, 142, 334-346. [CrossRef]

99. Belo, A.; Cheng, K.; Chahdi, A.; Shant, J.; Xie, G.; Khurana, S.; Raufman, J.P. Muscarinic receptor agonists stimulate human colon cancer cell migration and invasion. Am. J. Physiol. Gastrointest. Liver Physiol. 2011, 300, G749-G760. [CrossRef] 
100. Masur, K.; Niggemann, B.; Zanker, K.S.; Entschladen, F. Norepinephrine-induced migration of SW 480 colon carcinoma cells is inhibited by beta-blockers. Cancer Res. 2001, 61, 2866-2869.

101. Xie, G.; Cheng, K.; Shant, J.; Raufman, J.P. Acetylcholine-induced activation of M3 muscarinic receptors stimulates robust matrix metalloproteinase gene expression in human colon cancer cells. Am. J. Physiol. Gastrointest. Liver Physiol. 2009, 296, G755-G763. [CrossRef]

102. Raufman, J.P.; Cheng, K.; Saxena, N.; Chahdi, A.; Belo, A.; Khurana, S.; Xie, G. Muscarinic receptor agonists stimulate matrix metalloproteinase 1-dependent invasion of human colon cancer cells. Biochem. Biophys. Res. Commun. 2011, 415, 319-324. [CrossRef] [PubMed]

103. Said, A.H.; Hu, S.; Abutaleb, A.; Watkins, T.; Cheng, K.; Chahdi, A.; Kuppusamy, P.; Saxena, N.; Xie, G.; Raufman, J.P. Interacting post-muscarinic receptor signaling pathways potentiate matrix metalloproteinase-1 expression and invasion of human colon cancer cells. Biochem. J. 2017, 474, 647-665. [CrossRef] [PubMed]

104. Nocito, A.; Dahm, F.; Jochum, W.; Jang, J.H.; Georgiev, P.; Bader, M.; Graf, R.; Clavien, P.A. Serotonin regulates macrophage-mediated angiogenesis in a mouse model of colon cancer allografts. Cancer Res. 2008, 68, 5152-5158. [CrossRef]

105. Tang, J.; Wang, Z.; Liu, J.; Zhou, C.; Chen, J. Downregulation of 5-hydroxytryptamine receptor 3A expression exerts an anticancer activity against cell growth in colorectal carcinoma cells in vitro. Oncol. Lett. 2018, 16, 6100-6108. [CrossRef]

106. Ataee, R.; Ajdary, S.; Rezayat, M.; Shokrgozar, M.A.; Shahriari, S.; Zarrindast, M.R. Study of 5 HT3 and HT4 receptor expression in HT-29 cell line and human colon adenocarcinoma tissues. Arch. Iran. Med. 2010, 13, 120-125.

107. Ataee, R.; Ajdary, S.; Zarrindast, M.; Rezayat, M.; Hayatbakhsh, M.R. Anti-mitogenic and apoptotic effects of 5-HT1B receptor antagonist on HT-29 colorectal cancer cell line. J. Cancer Res. Clin. Oncol. 2010, 136, 1461-1469. [CrossRef]

108. Sui, H.; Xu, H.; Ji, Q.; Liu, X.; Zhou, L.; Song, H.; Zhou, X.; Xu, Y.; Chen, Z.; Cai, J.; et al. 5-hydroxytryptamine receptor (5-HT1DR) promotes colorectal cancer metastasis by regulating Axin1/ $\beta$-catenin/MMP-7 signaling pathway. Oncotarget 2015, 6, 25975-25987. [CrossRef]

109. Nguyen, L.; Ager, E.I.; Neo, J.; Christophi, C. Regulation of colorectal cancer cell epithelial to mesenchymal transition by the renin angiotensin system. J. Gastroenterol. Hepatol. 2016, 31, 1773-1782. [CrossRef]

110. Wang, R.; Löhr, C.V.; Fischer, K.; Dashwood, W.M.; Greenwood, J.A.; Ho, E.; Williams, D.E.; Ashktorab, H.; Dashwood, M.R.; Dashwood, R.H. Epigenetic inactivation of endothelin-2 and endothelin-3 in colon cancer. Int. J. Cancer 2013, 132, 1004-1012. [CrossRef]

111. Inagaki, H.; Bishop, A.E.; Eimoto, T.; Polak, J.M. Autoradiographic localization of endothelin-1 binding sites in human colonic cancer tissue. J. Pathol. 1992, 168, 263-267. [CrossRef]

112. Bagnato, A.; Rosanò, L. The endothelin axis in cancer. Int. J. Biochem. Cell Biol. 2008, 40, 1443-1451. [CrossRef] [PubMed]

113. Barton, M.; Yanagisawa, M. Endothelin: 20 years from discovery to therapy. Can. J. Physiol. Pharmacol. 2008, 86, 485-498. [CrossRef] [PubMed]

114. Sørby, L.A.; Kleiveland, C.R.; Andersen, S.N.; Bukholm, I.R.; Jacobsen, M.B. The endothelin axis in the metastatic process of colon carcinoma. Anticancer Res. 2011, 31, 861-869. [PubMed]

115. Nie, S.; Zhou, J.; Bai, F.; Jiang, B.; Chen, J.; Zhou, J. Role of endothelin A receptor in colon cancer metastasis: In vitro and in vivo evidence. Mol. Carcinog. 2014, 53 (Suppl. 1), E85-E91. [CrossRef]

116. Kusuhara, M.; Yamaguchi, K.; Nagasaki, K.; Hayashi, C.; Suzaki, A.; Hori, S.; Handa, S.; Nakamura, Y.; Abe, K. Production of endothelin in human cancer cell lines. Cancer Res. 1990, 50, 3257-3261.

117. Asham, E.; Shankar, A.; Loizidou, M.; Fredericks, S.; Miller, K.; Boulos, P.B.; Burnstock, G.; Taylor, I. Increased endothelin-1 in colorectal cancer and reduction of tumour growth by ET(A) receptor antagonism. Br. J. Cancer 2001, 85, 1759-1763. [CrossRef]

118. Wang, Z.; Liu, P.; Zhou, X.; Wang, T.; Feng, X.; Sun, Y.P.; Xiong, Y.; Yuan, H.X.; Guan, K.L. Endothelin promotes colorectal tumorigenesis by activating YAP/TAZ. Cancer Res. 2017, 77, 2413-2423. [CrossRef]

119. Takizawa, S.; Uchide, T.; Adur, J.; Kozakai, T.; Kotake-Nara, E.; Quan, J.; Saida, K. Differential expression of endothelin-2 along the mouse intestinal tract. J. Mol. Endocrinol. 2005, 35, 201-209. [CrossRef] 
120. Stevenson, L.; Allen, W.L.; Turkington, R.; Jithesh, P.V.; Proutski, I.; Stewart, G.; Lenz, H.J.; Van Schaeybroeck, S.; Longley, D.B.; Johnston, P.G. Identification of galanin and its receptor GalR1 as novel determinants of resistance to chemotherapy and potential biomarkers in colorectal cancer. Clin. Cancer Res. 2012, 18, 5412-5426. [CrossRef]

121. Nagayoshi, K.; Ueki, T.; Tashiro, K.; Mizuuchi, Y.; Manabe, T.; Araki, H.; Oda, Y.; Kuhara, S.; Tanaka, M. Galanin plays an important role in cancer invasiveness and is associated with poor prognosis in stage II colorectal cancer. Oncol. Rep. 2015, 33, 539-546. [CrossRef]

122. Yu, H.G.; Schrader, H.; Otte, J.M.; Schmidt, W.E.; Schmitz, F. Rapid tyrosine phosphorylation of focal adhesion kinase, paxillin, and p130Cas by gastrin in human colon cancer cells. Biochem. Pharmacol. 2004, 67, 135-146. [CrossRef] [PubMed]

123. Yu, H.G.; Tong, S.L.; Ding, Y.M.; Ding, J.; Fang, X.M.; Zhang, X.F.; Liu, Z.J.; Zhou, Y.H.; Liu, Q.S.; Luo, H.S.; et al. Enhanced expression of cholecystokinin-2 receptor promotes the progression of colon cancer through activation of focal adhesion kinase. Int. J. Cancer 2006, 119, 2724-2732. [CrossRef] [PubMed]

124. Duckworth, C.A.; Clyde, D.; Worthley, D.L.; Wang, T.C.; Varro, A.; Pritchard, D.M. Progastrin-induced secretion of insulin-like growth factor 2 from colonic myofibroblasts stimulates colonic epithelial proliferation in mice. Gastroenterology 2013, 145, 197-208. [CrossRef] [PubMed]

125. Kermorgant, S.; Lehy, T. Glycine-extended gastrin promotes the invasiveness of human colon cancer cells. Biochem. Biophys. Res. Commun. 2001, 285, 136-141. [CrossRef]

126. Hellmich, M.R.; Rui, X.L.; Hellmich, H.L.; Fleming, R.Y.; Evers, B.M.; Townsend, C.M., Jr. Human colorectal cancers express a constitutively active cholecystokinin-B/gastrin receptor that stimulates cell growth. J. Biol. Chem. 2000, 275, 32122-32128. [CrossRef]

127. Song, D.H.; Kaufman, J.C.; Borodyansky, L.; Albanese, C.; Pestell, R.G.; Wolfe, M.M. Gastrin stabilises beta-catenin protein in mouse colorectal cancer cells. Br. J. Cancer 2005, 92, 1581-1587. [CrossRef]

128. Cao, J.; Yu, J.P.; Liu, C.H.; Zhou, L.; Yu, H.G. Effects of gastrin 17 on beta-catenin/Tcf-4 pathway in Colo320WT colon cancer cells. World J. Gastroenterol. 2006, 12, 7482-7487. [CrossRef]

129. Colucci, R.; Blandizzi, C.; Ghisu, N.; Florio, T.; Del Tacca, M. Somatostatin inhibits colon cancer cell growth through cyclooxygenase-2 downregulation. Br. J. Pharmacol. 2008, 155, 198-209. [CrossRef]

130. Marshall, K.M.; Patel, O.; Bramante, G.; Laval, M.; Yim, M.; Baldwin, G.S.; Shulkes, A. The C-terminal flanking peptide of progastrin induces gastric cell apoptosis and stimulates colonic cell division in vivo. Peptides 2013, 46, 83-93. [CrossRef]

131. Jin, G.; Sakitani, K.; Wang, H.; Jin, Y.; Dubeykovskiy, A.; Worthley, D.L.; Tailor, Y.; Wang, T.C. The G-protein coupled receptor 56 , expressed in colonic stem and cancer cells, binds progastrin to promote proliferation and carcinogenesis. Oncotarget 2017, 8, 40606-40619. [CrossRef]

132. Goode, T.; O'Connor, T.; Hopkins, A.; Moriarty, D.; O’Sullivan, G.C.; Collins, J.K.; O’Donoghue, D.; Baird, A.W.; O'Connell, J.; Shanahan, F. Neurokinin-1 receptor (NK-1R) expression is induced in human colonic epithelial cells by proinflammatory cytokines and mediates proliferation in response to substance P. J. Cell Physiol. 2003, 197, 30-41. [CrossRef]

133. Carroll, R.E.; Matkowskyj, K.A.; Tretiakova, M.S.; Battey, J.F.; Benya, R.V. Gastrin-releasing peptide is a mitogen and a morphogen in murine colon cancer. Cell Growth Differ. 2000, 11, 385-393. [PubMed]

134. Carroll, R.E.; Ostrovskiy, D.; Lee, S.; Danilkovich, A.; Benya, R.V. Characterization of gastrin-releasing peptide and its receptor aberrantly expressed by human colon cancer cell lines. Mol. Pharmacol. 2000, 58, 601-607. [CrossRef] [PubMed]

135. Chave, H.S.; Gough, A.C.; Palmer, K.; Preston, S.R.; Primrose, J.N. Bombesin family receptor and ligand gene expression in human colorectal cancer and normal mucosa. Br. J. Cancer 2000, 82, 124-130. [CrossRef] [PubMed]

136. Matusiak, D.; Glover, S.; Nathaniel, R.; Matkowskyj, K.; Yang, J.; Benya, R.V. Neuromedin B and its receptor are mitogens in both normal and malignant epithelial cells lining the colon. Am. J. Physiol. Gastrointest. Liver Physiol. 2005, 288, G718-G728. [CrossRef]

137. Jeppsson, S.; Srinivasan, S.; Chandrasekharan, B. Neuropeptide Y (NPY) promotes inflammation-induced tumorigenesis by enhancing epithelial cell proliferation. Am. J. Physiol. Gastrointest. Liver Physiol. 2017, 312, G103-G111. [CrossRef] 
138. Garnier, A.; Vykoukal, J.; Hubertus, J.; Alt, E.; von Schweinitz, D.; Kappler, R.; Berger, M.; Ilmer, M. Targeting the neurokinin-1 receptor inhibits growth of human colon cancer cells. Int. J. Oncol. 2015, 47, 151-160. [CrossRef]

139. Martinez, V.G.; O'Driscoll, L. Neuromedin U: A multifunctional neuropeptide with pleiotropic roles. Clin. Chem. 2015, 61, 471-482. [CrossRef]

140. Ramos-Álvarez, I.; Moreno, P.; Mantey, S.A.; Nakamura, T.; Nuche-Berenguer, B.; Moody, T.W.; Coy, D.H.; Jensen, R.T. Insights into bombesin receptors and ligands: Highlighting recent advances. Peptides 2015, 72, 128-144. [CrossRef]

141. Cassano, G.; Resta, N.; Gasparre, G.; Lippe, C.; Guanti, G. The proliferative response of HT-29 human colon adenocarcinoma cells to bombesin-like peptides. Cancer Lett. 2001, 172, 151-157. [CrossRef]

142. Rivera, C.A.; Ahlberg, N.C.; Taglia, L.; Kumar, M.; Blunier, A.; Benya, R.V. Expression of GRP and its receptor is associated with improved survival in patients with colon cancer. Clin. Exp. Metastasis 2009, 26, 663-671. [CrossRef] [PubMed]

143. Tell, R.; Rivera, C.A.; Eskra, J.; Taglia, L.N.; Blunier, A.; Wang, Q.T.; Benya, R.V. Gastrin-releasing peptide signaling alters colon cancer invasiveness via heterochromatin protein 1Hs $\beta$. Am. J. Pathol. 2011, 178, 672-678. [CrossRef] [PubMed]

144. Taglia, L.; Matusiak, D.; Matkowskyj, K.A.; Benya, R.V. Gastrin-releasing peptide mediates its morphogenic properties in human colon cancer by upregulating intracellular adhesion protein-1 (ICAM-1) via focal adhesion kinase. Am. J. Physiol. Gastrointest. Liver Physiol. 2007, 292, G182-G190. [CrossRef] [PubMed]

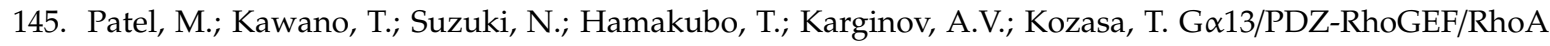
signaling is essential for gastrin-releasing peptide receptor-mediated colon cancer cell migration. Mol. Pharmacol. 2014, 86, 252-262. [CrossRef] [PubMed]

146. Patel, O.; Clyde, D.; Chang, M.; Nordlund, M.S.; Steel, R.; Kemp, B.E.; Pritchard, D.M.; Shulkes, A.; Baldwin, G.S. Pro-GRP-derived peptides are expressed in colorectal cancer cells and tumors and are biologically active in vivo. Endocrinology 2012, 153, 1082-1092. [CrossRef]

147. Carraway, R.E.; Plona, A.M. Involvement of neurotensin in cancer growth: Evidence, mechanisms and development of diagnostic tools. Peptides 2006, 27, 2445-2460. [CrossRef]

148. Wu, Z.; Martinez-Fong, D.; Trédaniel, J.; Forgez, P. Neurotensin and its high affinity receptor 1 as a potential pharmacological target in cancer therapy. Front. Endocrinol. 2013, 3, 184. [CrossRef]

149. Hu, H.R.; Dong, Z.; Yi, L.; He, X.Y.; Zhang, Y.L.; Liu, Y.L.; Cui, H.J. Function and mechanism of neurotensin (NTS) and its receptor 1 (NTSR1) in occurrence and development of tumors. Zhongguo Zhong Yao Za Zhi 2015, 40, 2524-2536.

150. Ouyang, Q.; Zhou, J.; Yang, W.; Cui, H.; Xu, M.; Yi, L. Oncogenic role of neurotensin and neurotensin receptors in various cancers. Clin. Exp. Pharmacol. Physiol. 2017, 44, 841-846. [CrossRef]

151. Qiu, S.; Pellino, G.; Fiorentino, F.; Rasheed, S.; Darzi, A.; Tekkis, P.; Kontovounisios, C. A review of the role of neurotensin and its receptors in colorectal cancer. Gastroenterol. Res. Pract. 2017, 2017, 6456257. [CrossRef]

152. Maoret, J.J.; Anini, Y.; Rouyer-Fessard, C.; Gully, D.; Laburthe, M. Neurotensin and a non-peptide neurotensin receptor antagonist control human colon cancer cell growth in cell culture and in cells xenografted into nude mice. Int. J. Cancer 1999, 80, 448-454. [CrossRef]

153. Martin, S.; Navarro, V.; Vincent, J.P.; Mazella, J. Neurotensin receptor-1 and -3 complex modulates the cellular signaling of neurotensin in the HT-29 cell line. Gastroenterology 2002, 123, 1135-1143. [CrossRef] [PubMed]

154. Massa, F.; Tormo, A.; Béraud-Dufour, S.; Coppola, T.; Mazella, J. Neurotensin-induced Erk1/2 phosphorylation and growth of human colonic cancer cells are independent from growth factors receptors activation. Biochem. Biophys. Res. Commun. 2011, 414, 118-122. [CrossRef] [PubMed]

155. Wang, X.; Jackson, L.N.; Johnson, S.M.; Wang, Q.; Evers, B.M. Suppression of neurotensin receptor type 1 expression and function by histone deacetylase inhibitors in human colorectal cancers. Mol. Cancer Ther. 2010, 9, 2389-2398. [CrossRef]

156. Bakirtzi, K.; Hatziapostolou, M.; Karagiannides, I.; Polytarchou, C.; Jaeger, S.; Iliopoulos, D.; Pothoulakis, C. Neurotensin signaling activates microRNAs-21 and -155 and Akt, promotes tumor growth in mice, and is increased in human colon tumors. Gastroenterology 2011, 141, 1749-1761. [CrossRef]

157. Kim, J.T.; Weiss, H.L.; Evers, B.M. Diverse expression patterns and tumorigenic role of neurotensin signaling components in colorectal cancer cells. Int. J. Oncol. 2017, 50, 2200-2206. [CrossRef] 
158. Hejna, M.; Hamilton, G.; Brodowicz, T.; Haberl, I.; Fiebiger, W.C.; Scheithauer, W.; Virgolini, I.; Köstler, W.J.; Oberhuber, G.; Raderer, M. Serum levels of vasoactive intestinal peptide (VIP) in patients with adenocarcinomas of the gastrointestinal tract. Anticancer Res. 2001, 21, 1183-1187.

159. Le, S.V.; Yamaguchi, D.J.; McArdle, C.A.; Tachiki, K.; Pisegna, J.R.; Germano, P. PAC1 and PACAP expression, signaling, and effect on the growth of HCT8, human colonic tumor cells. Regul. Pept. 2002, 109, 115-125. [CrossRef]

160. Alleaume, C.; Eychène, A.; Caigneaux, E.; Muller, J.M.; Philippe, M. Vasoactive intestinal peptide stimulates proliferation in HT-29 human colonic adenocarcinoma cells: Concomitant activation of Ras/Rap1-B-Raf-ERK signalling pathway. Neuropeptides 2003, 37, 98-104. [CrossRef]

161. Liu, Y.; Fang, X.; Yuan, J.; Sun, Z.; Li, C.; Li, R.; Li, L.; Zhu, C.; Wan, R.; Guo, R.; et al. The role of corticotropin-releasing hormone receptor 1 in the development of colitis-associated cancer in mouse model. Endocr. Relat. Cancer 2014, 21, 639-651. [CrossRef]

162. Yagi, T.; Kubota, E.; Koyama, H.; Tanaka, T.; Kataoka, H.; Imaeda, K.; Joh, T. Glucagon promotes colon cancer cell growth via regulating AMPK and MAPK pathways. Oncotarget 2018, 9, 10650-10664. [CrossRef] [PubMed]

163. Janssen, P.; Rotondo, A.; Mulé, F.; Tack, J. Review article: A comparison of glucagon-like peptides 1 and 2. Aliment. Pharmacol. Ther. 2013, 37, 18-36. [CrossRef] [PubMed]

164. Koehler, J.A.; Kain, T.; Drucker, D.J. Glucagon-like peptide-1 receptor activation inhibits growth and augments apoptosis in murine CT26 colon cancer cells. Endocrinology 2011, 152, 3362-3372. [CrossRef] [PubMed]

165. Wenjing, H.; Shuang, Y.; Weisong, L.; Haipeng, X. Exendin-4 does not modify growth or apoptosis of human colon cancer cells. Endocr. Res. 2017, 42, 209-218. [CrossRef]

166. Rowland, K.J.; Trivedi, S.; Lee, D.; Wan, K.; Kulkarni, R.N.; Holzenberger, M.; Brubaker, P.L. Loss of glucagon-like peptide-2-induced proliferation following intestinal epithelial insulin-like growth factor-1-receptor deletion. Gastroenterology 2011, 141, 2166-2175. [CrossRef] [PubMed]

167. Shi, X.; Li, X.; Wang, Y.; Zhang, K.; Zhou, F.; Chan, L.; Li, D.; Guan, X. Glucagon-like peptide-2-stimulated protein synthesis through the PI 3-kinase-dependent Akt-mTOR signaling pathway. Am. J. Physiol. Endocrinol. Metab. 2011, 300, E554-E563. [CrossRef]

168. Kannen, V.; Garcia, S.B.; Stopper, H.; Waaga-Gasser, A.M. Glucagon-like peptide 2 in colon carcinogenesis: Possible target for anti-cancer therapy? Pharmacol. Ther. 2013, 139, 87-94. [CrossRef]

169. Thulesen, J.; Hartmann, B.; Hare, K.J.; Kissow, H.; Ørskov, C.; Holst, J.J.; Poulsen, S.S. Glucagon-like peptide 2 (GLP-2) accelerates the growth of colonic neoplasms in mice. Gut 2004, 53, 1145-1150. [CrossRef]

170. Shawe-Taylor, M.; Kumar, J.D.; Holden, W.; Dodd, S.; Varga, A.; Giger, O.; Varro, A.; Dockray, G.J. Glucagon-like petide-2 acts on colon cancer myofibroblasts to stimulate proliferation, migration and invasion of both myofibroblasts and cancer cells via the IGF pathway. Peptides 2017, 91, 49-57. [CrossRef]

171. Benali, N.; Ferjoux, G.; Puente, E.; Buscail, L.; Susini, C. Somatostatin receptors. Digestion 2000, 62 (Suppl. 1), 27-32. [CrossRef]

172. Chen, J.S.; Liang, Q.M.; Li, H.S.; Yang, J.; Wang, S.; Long, J.W. Octreotide inhibits growth of colonic cancer SW480 cells by modulating the Wnt/P-catenin pathway. Pharmazie 2009, 64, 126-131. [PubMed]

173. Wang, S.; Bao, Z.; Liang, Q.M.; Long, J.W.; Xiao, Z.S.; Jiang, Z.J.; Liu, B.; Yang, J.; Long, Z.X. Octreotide stimulates somatostatin receptor-induced apoptosis of SW480 colon cancer cells by activation of glycogen synthase kinase-3 $\beta$, A Wnt/ $\beta$-catenin pathway modulator. Hepatogastroenterology 2013, 60, 1639-1646. [PubMed]

174. Modarai, S.R.; Opdenaker, L.M.; Viswanathan, V.; Fields, J.Z.; Boman, B.M. Somatostatin signaling via SSTR1 contributes to the quiescence of colon cancer stem cells. BMC Cancer 2016, 16, 941. [CrossRef] [PubMed]

175. Skaper, S.D. The neurotrophin family of neurotrophic factors: An overview. Methods Mol. Biol. 2012, 846, 1-12. [CrossRef]

176. Akil, H.; Perraud, A.; Jauberteau, M.O.; Mathonnet, M. Tropomyosin-related kinase B/brain derived-neurotrophic factor signaling pathway as a potential therapeutic target for colorectal cancer. World J. Gastroenterol. 2016, 22, 490-500. [CrossRef]

177. Blondy, S.; Christou, N.; David, V.; Verdier, M.; Jauberteau, M.O.; Mathonnet, M.; Perraud, A. Neurotrophins and their involvement in digestive cancers. Cell Death Dis. 2019, 10, 123. [CrossRef] 
178. Genevois, A.L.; Ichim, G.; Coissieux, M.M.; Lambert, M.P.; Lavial, F.; Goldschneider, D.; Jarrosson-Wuilleme, L.; Lepinasse, F.; Gouysse, G.; Herceg, Z.; et al. Dependence receptor TrKC is a putative colon cancer tumor suppressor. Proc. Natl. Acad. Sci. USA 2013, 110, 3017-3022. [CrossRef]

179. Luo, Y.; Kaz, A.M.; Kanngurn, S.; Welsch, P.; Morris, S.M.; Wang, J.; Lutterbaugh, J.D.; Markowitz, S.D.; Grady, W.M. NTRK3 is a potential tumor suppressor gene commonly inactivated by epigenetic mechanisms in colorectal cancer. PLoS Genet. 2013, 9, e1003552. [CrossRef]

180. Akil, H.; Perraud, A.; Mélin, C.; Jauberteau, M.O.; Mathonnet, M. Fine-tuning roles of endogenous brain-derived neurotrophic factor, TrKB and sortilin in colorectal cancer cell survival. PLoS ONE 2011, 6, e25097. [CrossRef]

181. Fan, M.; Sun, J.; Wang, W.; Fan, J.; Wang, L.; Zhang, X.; Yang, A.; Wang, W.; Zhang, R.; Li, J. Tropomyosin-related kinase B promotes distant metastasis of colorectal cancer through protein kinase B-mediated anoikis suppression and correlates with poor prognosis. Apoptosis 2014, 19, 860-870. [CrossRef]

182. Sasahira, T.; Ueda, N.; Kurihara, M.; Matsushima, S.; Ohmori, H.; Fujii, K.; Bhawal, U.K.; Yamamoto, K.; Kirita, T.; Kuniyasu, H. Tropomyosin receptor kinases B and C are tumor progressive and metastatic marker in colorectal carcinoma. Hum. Pathol. 2013, 44, 1098-1106. [CrossRef] [PubMed]

183. Tanaka, K.; Okugawa, Y.; Toiyama, Y.; Inoue, Y.; Saigusa, S.; Kawamura, M.; Araki, T.; Uchida, K.; Mohri, Y.; Kusunoki, M. Brain-derived neurotrophic factor (BDNF)-induced tropomyosin-related kinase B (TrK B) signaling is a potential therapeutic target for peritoneal carcinomatosis arising from colorectal cancer. PLoS ONE 2014, 9, e96410. [CrossRef] [PubMed]

184. Mazouffre, C.; Geyl, S.; Perraud, A.; Blondy, S.; Jauberteau, M.O.; Mathonnet, M.; Verdier, M. Dual inhibition of BDNF/TrKB and autophagy: A promising therapeutic approach for colorectal cancer. J. Cell Mol. Med. 2017, 21, 2610-2622. [CrossRef] [PubMed]

185. Sunami, E.; Tsuno, N.; Osada, T.; Saito, S.; Kitayama, J.; Tomozawa, S.; Tsuruo, T.; Shibata, Y.; Muto, T.; Nagawa, H. MMP-1 is a prognostic marker for hematogenous metastasis of colorectal cancer. Oncologist 2000, 5, 108-114. [CrossRef]

186. Wong, J.C.; Chan, S.K.; Schaeffer, D.F.; Sagaert, X.; Lim, H.J.; Kennecke, H.; Owen, D.A.; Suh, K.W.; Kim, Y.B.; Tai, I.T. Absence of MMP2 expression correlates with poor clinical outcomes in rectal cancer, and is distinct from MMP1-related outcomes in colon cancer. Clin. Cancer Res. 2011, 17, 4167-4176. [CrossRef] [PubMed]

187. Xu, H.; Ren, Y.J.; Liu, K.; Min, X.L.; Yang, L.; Zhou, Y.; Zheng, J.; Yang, C. Correlations of serum VEGF and MMP-2 levels with CLM in CRC patients and effects of TACE on their expressions. Eur. Rev. Med. Pharmacol. Sci. 2018, 22, 3394-3401. [CrossRef]

188. Ducarouge, B.; Pelissier-Rota, M.; Lainé, M.; Cristina, N.; Vachez, Y.; Scoazec, J.Y.; Bonaz, B.; Jacquier-Sarlin, M. CRF2 signaling is a novel regulator of cellular adhesion and migration in colorectal cancer cells. PLoS ONE 2013, 8, e79335. [CrossRef]

189. Béraud-Dufour, S.; Devader, C.; Massa, F.; Roulot, M.; Coppola, T.; Mazella, J. Focal adhesion kinase-dependent role of the soluble form of neurotensin receptor-3/sortilin in colorectal cancer cell dissociation. Int. J. Mol. Sci. 2016, 17, 1860. [CrossRef]

190. Dal Farra, C.; Sarret, P.; Navarro, V.; Botto, J.M.; Mazella, J.; Vincent, J.P. Involvement of the neurotensin receptor subtype NTR3 in the growth effect of neurotensin on cancer cell lines. Int. J. Cancer 2001, 92, 503-509. [CrossRef]

191. Massa, F.; Devader, C.; Béraud-Dufour, S.; Brau, F.; Coppola, T.; Mazella, J. Focal adhesion kinase dependent activation of the PI3 kinase pathway by the functional soluble form of neurotensin receptor-3 in HT-29 cells. Int. J. Biochem. Cell Biol. 2013, 45, 952-959. [CrossRef]

192. Massa, F.; Devader, C.; Lacas-Gervais, S.; Béraud-Dufour, S.; Coppola, T.; Mazella, J. Impairement of HT-29 cancer cells cohesion by the soluble form of neurotensin receptor-3. Genes Cancer 2014, 5, 240-249. [CrossRef] [PubMed]

193. Fujikawa, H.; Tanaka, K.; Toiyama, Y.; Saigusa, S.; Inoue, Y.; Uchida, K.; Kusunoki, M. High TrKB expression levels are associated with poor prognosis and EMT induction in colorectal cancer cells. J. Gastroenterol. 2012, 47, 775-784. [CrossRef] [PubMed]

194. Tilan, J.; Kitlinska, J. Sympathetic neurotransmitters and tumor angiogenesis-link between stress and cancer progression. J. Oncol. 2010, 2010, 539706. [CrossRef] [PubMed] 
195. Clarke, P.A.; Dickson, J.H.; Harris, J.C.; Grabowska, A.; Watson, S.A. Gastrin enhances the angiogenic potential of endothelial cells via modulation of heparin-binding epidermal-like growth factor. Cancer Res. 2006, 66, 3504-3512. [CrossRef]

196. Najib, S.; Kowalski-Chauvel, A.; Do, C.; Roche, S.; Cohen-Jonathan-Moyal, E.; Seva, C. Progastrin a new pro-angiogenic factor in colorectal cancer. Oncogene 2015, 34, 3120-3130. [CrossRef]

197. Reubi, J.C.; Mazzucchelli, L.; Hennig, I.; Laissue, J.A. Local up-regulation of neuropeptide receptors in host blood vessels around human colorectal cancers. Gastroenterology 1996, 110, 1719-1726. [CrossRef]

198. Zhou, L.; Luo, Y.; Sato, S.; Tanabe, E.; Kitayoshi, M.; Fujiwara, R.; Sasaki, T.; Fujii, K.; Ohmori, H.; Kuniyasu, H. Role of two types of angiotensin II receptors in colorectal carcinoma progression. Pathobiology 2014, 81, 169-175. [CrossRef]

199. Au, S.H.; Storey, B.D.; Moore, J.C.; Tang, Q.; Chen, Y.L.; Javaid, S.; Sarioglu, A.F.; Sullivan, R.; Madden, M.W.; O'Keefe, R.; et al. Clusters of circulating tumor cells traverse capillary-sized vessels. Proc. Natl. Acad. Sci. USA 2016, 113, 4947-4952. [CrossRef] [PubMed]

200. Nanduri, L.K.; Hissa, B.; Weitz, J.; Schölch, S.; Bork, U. The prognostic role of circulating tumor cells in colorectal cancer. Expert Rev. Anticancer Ther. 2019, 19, 1077-1088. [CrossRef]

201. Christou, N.; Meyer, J.; Popeskou, S.; David, V.; Toso, C.; Buchs, N.; Liot, E.; Robert, J.; Ris, F.; Mathonnet, M. Circulating tumour cells, circulating tumour DNA and circulating tumour miRNA in blood assays in the different steps of colorectal cancer management, a review of the evidence in 2019. Biomed. Res. Int. 2019, 2019, 5953036. [CrossRef]

202. Wei, C.; Yang, C.; Wang, S.; Shi, D.; Zhang, C.; Lin, X.; Liu, Q.; Dou, R.; Xiong, B. Crosstalk between cancer cells and tumor associated macrophages is required for mesenchymal circulating tumor cell-mediated colorectal cancer metastasis. Mol. Cancer 2019, 18, 64. [CrossRef] [PubMed]

203. Wang, Z.H.; Ding, K.F.; Yu, J.K.; Zhai, X.H.; Ruan, S.Q.; Wang, S.W.; Zhu, Y.L.; Zheng, S.; Zhang, S.Z. Proteomic analysis of primary colon cancer-associated fibroblasts using the SELDI-ProteinChip platform. J. Zhejiang Univ. Sci. B. 2012, 13, 159-167. [CrossRef] [PubMed]

204. Takatsuna, M.; Morohashi, S.; Yoshizawa, T.; Hirai, H.; Haga, T.; Ota, R.; Wu, Y.; Morohashi, H.; Hakamada, K.; Terai, S.; et al. Myofibroblasts of the muscle layer stimulate the malignant potential of colorectal cancer. Oncol. Rep. 2016, 36, 1251-1257. [CrossRef] [PubMed]

205. Van den Eynde, M.; Mlecnik, B.; Bindea, G.; Fredriksen, T.; Church, S.E.; Lafontaine, L.; Haicheur, N.; Marliot, F.; Angelova, M.; Vasaturo, A.; et al. The link between the multiverse of immune microenvironments in metastases and the survival of colorectal cancer patients. Cancer Cell. 2018, 34, 1012-1026. [CrossRef]

206. Chen, W.Z.; Jiang, J.X.; Yu, X.Y.; Xia, W.J.; Yu, P.X.; Wang, K.; Zhao, Z.Y.; Chen, Z.G. Endothelial cells in colorectal cancer. World J. Gastrointest. Oncol. 2019, 11, 946-956. [CrossRef]

207. Ong, B.A.; Vega, K.J.; Houchen, C.W. Intestinal stem cells and the colorectal cancer microenvironment. World J. Gastroenterol. 2014, 20, 1898-1909. [CrossRef]

208. Shankar, A.; Loizidou, M.; Aliev, G.; Fredericks, S.; Holt, D.; Boulos, P.B.; Burnstock, G.; Taylor, I. Raised endothelin 1 levels in patients with colorectal liver metastases. Br. J. Surg. 1998, 85, 502-506. [CrossRef]

209. Simpson, R.A.; Dickinson, T.; Porter, K.E.; London, N.J.; Hemingway, D.M. Raised levels of plasma big endothelin 1 in patients with colorectal cancer. Br. J. Surg. 2000, 87, 1409-1413. [CrossRef]

210. Sereti, E.; Gavriil, A.; Agnantis, N.; Golematis, V.C.; Voloudakis-Baltatzis, I.E. Immunoelectron study of somatostatin, gastrin and glucagon in human colorectal adenocarcinomas and liver metastases. Anticancer Res. 2002, 22, 2117-2123.

211. Chao, C.; Tallman, M.L.; Ives, K.L.; Townsend, C.M., Jr.; Hellmich, M.R. Gastrointestinal hormone receptors in primary human colorectal carcinomas. J. Surg. Res. 2005, 129, 313-321. [CrossRef]

212. Seretis, E.; Konstantinidou, A.; Arnogiannakis, N.; Xinopoulos, D.; Voloudakis-Baltatzis, I.E. Mucinous colorectal adenocarcinoma with signet-ring cells: Immunohistochemical and ultrastructural study. Ultrastruct. Pathol. 2010, 34, 337-343. [CrossRef] [PubMed]

213. Fiocca, R.; Rindi, G.; Capella, C.; Grimelius, L.; Polak, J.M.; Schwartz, T.W.; Yanaihara, N.; Solcia, E. Glucagon, glicentin, proglucagon, PYY, PP and proPP-icosapeptide immunoreactivities of rectal carcinoid tumors and related non-tumor cells. Regul. Pept. 1987, 17, 9-29. [CrossRef] 
214. Seretis, E.C.; Agnantis, N.J.; Golematis, V.C.; Voloudakis-Balatzis, I.E. Electron immunocytochemical demonstration of serotonin, vasoactive intestinal polypeptide, bombesin, somatostatin and glucagon in mirror biopsies from primary colorectal adenocarcinoma. J. Exp. Clin. Cancer Res. 2004, 23, 477-484. [PubMed]

215. Beng1, G.; Kayahan, H.; Akarsu, M.; Aysal, A.; Sağol, O.; Meral, M.; Akpinar, H. Does glucagon like peptide-2 receptor expression have any effect on the development of human colorectal cancer? Turk. J. Gastroenterol. 2011, 22, 388-394. [CrossRef]

216. Reubi, J.C.; Läderach, U.; Waser, B.; Gebbers, J.O.; Robberecht, P.; Laissue, J.A. Vasoactive intestinal peptide/pituitary adenylate cyclase-activating peptide receptor subtypes in human tumors and their tissues of origin. Cancer Res. 2000, 60, 3105-3112.

217. Reubi, J.C.; Waser, B.; Vale, W.; Rivier, J. Expression of CRF1 and CRF2 receptors in human cancers. J. Clin. Endocrinol. Metab. 2003, 88, 3312-3320. [CrossRef]

218. Chen, X.Y.; Ru, G.Q.; Ma, Y.Y.; Xie, J.; Chen, W.Y.; Wang, H.J.; Wang, S.B.; Li, L.; Jin, K.T.; He, X.L.; et al. High expression of substance $\mathrm{P}$ and its receptor neurokinin-1 receptor in colorectal cancer is associated with tumor progression and prognosis. Onco. Targets Ther. 2016, 9, 3595-3602. [CrossRef]

219. Zhang, S.; Chatterjee, T.; Godoy, C.; Wu, L.; Liu, Q.J.; Carmon, K.S. GPR56 drives colorectal tumor growth and promotes drug resistance through upregulation of MDR1 expression via a RhoA-mediated mechanism. Mol. Cancer Res. 2019, 17, 2196-2207. [CrossRef]

220. Tripathi, S.; Flobak, Å.; Chawla, K.; Baudot, A.; Bruland, T.; Thommesen, L.; Kuiper, M.; Lægreid, A. The gastrin and cholecystokinin receptors mediated signaling network: A scaffold for data analysis and new hypotheses on regulatory mechanisms. BMC Syst. Biol. 2015, 9, 40. [CrossRef]

221. Leiszter, K.; Sipos, F.; Galamb, O.; Krenács, T.; Veres, G.; Wichmann, B.; Fûri, I.; Kalmár, A.; Patai, Á.V.; Tóth, K.; et al. Promoter hypermethylation-related reduced somatostatin production promotes uncontrolled cell proliferation in colorectal cancer. PLOS ONE 2015, 10, e0118332. [CrossRef]

222. Buscail, L.; Saint-Laurent, N.; Chastre, E.; Vaillant, J.C.; Gespach, C.; Capella, G.; Kalthoff, H.; Lluis, F.; Vaysse, N.; Susini, C. Loss of sst2 somatostatin receptor gene expression in human pancreatic and colorectal cancer. Cancer Res. 1996, 56, 1823-1827. [PubMed]

223. Evangelou, I.; Petraki, C.; Msaouel, P.; Scorilas, A.; Sdrolia, E.; Padazi, G.; Koborozos, V.; Koutsilieris, M. Immunohistochemical expression of somatostatin receptor subtypes 2 and 5 in colorectal cancer. Eur. J. Clin. Investig. 2012, 42, 777-783. [CrossRef] [PubMed]

224. Neo, J.H.; Ager, E.I.; Angus, P.W.; Zhu, J.; Herath, C.B.; Christophi, C. Changes in the renin angiotensin system during the development of colorectal cancer liver metastases. BMC Cancer 2010, 10, 134. [CrossRef] [PubMed]

225. Wen, S.W.; Ager, E.I.; Neo, J.; Christophi, C. The renin angiotensin system regulates Kupffer cells in colorectal liver metastases. Cancer Biol. Ther. 2013, 14, 720-727. [CrossRef]

226. Shimizu, Y.; Amano, H.; Ito, Y.; Betto, T.; Yamane, S.; Inoue, T.; Nishizawa, N.; Matsui, Y.; Kamata, M.; Nakamura, M.; et al. Angiotensin II subtype 1a receptor signaling in resident hepatic macrophages induces liver metastasis formation. Cancer Sci. 2017, 108, 1757-1768. [CrossRef]

227. Gui, X.; Liu, S.; Yan, Y.; Gao, Z. Neurotensin receptor 1 overexpression in inflammatory bowel diseases and colitis-associated neoplasia. World J. Gastroenterol. 2013, 19, 4504-4510. [CrossRef]

228. Maoret, J.J.; Pospaï, D.; Rouyer-Fessard, C.; Couvineau, A.; Laboisse, C.; Voisin, T.; Laburthe, M. Neurotensin receptor and its mRNA are expressed in many human colon cancer cell lines but not in normal colonic epithelium: Binding studies and RT-PCR experiments. Biochem. Biophys. Res. Commun. 1994, 203, 465-471. [CrossRef]

229. Gui, X.; Guzman, G.; Dobner, P.R.; Kadkol, S.S. Increased neurotensin receptor-1 expression during progression of colonic adenocarcinoma. Peptides. 2008, 29, 1609-1615. [CrossRef]

230. Raggi, C.C.; Cianchi, F.; Valanzano, R.; Smith, M.C.; Serio, M.; Maggi, M.; Orlando, C. Prognostic value of somatostatin receptor subtype 2 expression in colorectal cancer. Regul. Pept. 2005, 132, 23-26. [CrossRef]

231. Xia, Y.; Wang, D.; Zhang, N.; Wang, Z.; Pang, L. Plasma serotonin level is a predictor for recurrence and poor prognosis in colorectal cancer patients. J. Clin. Lab. Anal. 2018, 32. [CrossRef]

232. Peeters, C.F.; Thomas, C.M.; Sweep, F.C.; Span, P.N.; Wobbes, T.; Ruers, T.M. Elevated serum endothelin-1 levels in patients with colorectal cancer; relevance for prognosis. Int. J. Biol. Markers 2000, 15, 288-293. [CrossRef] [PubMed] 
233. Arun, C.; London, N.J.; Hemingway, D.M. Prognostic significance of elevated endothelin-1 levels in patients with colorectal Cancer. Int. J. Biol. Markers. 2004, 19, 32-37. [CrossRef]

234. Strofilas, A.; Lagoudianakis, E.E.; Seretis, C.; Pappas, A.; Koronakis, N.; Keramidaris, D.; Koukoutsis, I.; Chrysikos, I.; Manouras, I.; Manouras, A. Association of helicobacter pylori infection and colon cancer. J. Clin. Med. Res. 2012, 4, 172-176. [CrossRef] [PubMed]

235. Zhang, Q.Y.; Lv, Z.; Sun, L.P.; Dong, N.N.; Xing, C.Z.; Yuan, Y. Clinical significance of serum markers reflecting gastric function and $H$. pylori infection in colorectal cancer. J. Cancer 2019, 10, 2229-2236. [CrossRef]

236. Byrne, M.M.; McGregor, G.P.; Barth, P.; Rothmund, M.; Göke, B.; Arnold, R. Intestinal proliferation and delayed intestinal transit in a patient with a GLP-1-, GLP-2- and PYY-producing neuroendocrine carcinoma. Digestion 2001, 63, 61-68. [CrossRef]

237. Zygulska, A.L.; Furgala, A.; Kaszuba-Zwoińska, J.; Krzemieniecki, K.; Gil, K. Changes in plasma levels of cholecystokinin, neurotensin, VIP and PYY in gastric and colorectal cancer-Preliminary results. Peptides 2019, 122, 170148. [CrossRef]

238. Qiu, S.; Nikolaou, S.; Fiorentino, F.; Rasheed, S.; Darzi, A.; Cunningham, D.; Tekkis, P.; Kontovounisios, C. Exploratory Analysis of Plasma Neurotensin as a Novel Biomarker for Early Detection of Colorectal Polyp and cancer. Horm. Cancer 2019, 10, 128-135. [CrossRef]

239. Johansson, M.; Jönsson, M.; Norrgård, O.; Forsgren, S. New aspects concerning ulcerative colitis and colonic carcinoma: Analysis of levels of neuropeptides, neurotrophins, and TNFalpha/TNF receptor in plasma and mucosa in parallel with histological evaluation of the intestine. Inflamm. Bowel Dis. 2008, 14, 1331-1340. [CrossRef]

240. Lloyd, G.M.; Neal, C.P.; Arun, C.; London, N.J.; Hemingway, D.M. The prognostic value of circulating big endothelin-1 in patients undergoing potentially curative resection for colorectal cancer. Colorectal Dis. 2011, 13, 290-295. [CrossRef]

241. Selgrad, M.; Bornschein, J.; Kandulski, A.; Hille, C.; Weigt, J.; Roessner, A.; Wex, T.; Malfertheiner, P. Helicobacter pylori but not gastrin is associated with the development of colonic neoplasms. Int. J. Cancer 2014, 135, 1127-1131. [CrossRef]

242. Robertson, D.J.; Sandler, R.S.; Ahnen, D.J.; Greenberg, E.R.; Mott, L.A.; Cole, B.F.; Baron, J.A. Gastrin, helicobacter pylori, and colorectal adenomas. Clin. Gastroenterol. Hepatol. 2009, 7, 163-167. [CrossRef] [PubMed]

243. Georgopoulos, S.D.; Polymeros, D.; Triantafyllou, K.; Spiliadi, C.; Mentis, A.; Karamanolis, D.G.; Ladas, S.D. Hypergastrinemia is associated with increased risk of distal colon adenomas. Digestion 2006, 74, 42-46. [CrossRef] [PubMed]

244. Zhang, K.; Mao, T.; He, Z.; Wu, X.; Peng, Y.; Chen, Y.; Dong, Y.; Ruan, Z.; Wang, Z. Angiotensin I-converting enzyme gene plays a crucial role in the pathology of carcinomas in colorectal cancer. Artif. Cells Nanomed. Biotechnol. 2019, 47, 2500-2506. [CrossRef] [PubMed]

245. Koehler, A.; Bataille, F.; Schmid, C.; Ruemmele, P.; Waldeck, A.; Blaszyk, H.; Hartmann, A.; Hofstaedter, F.; Dietmaier, W. Gene expression profiling of colorectal cancer and metastases divides tumours according to their clinicopathological stage. J. Pathol. 2004, 204, 65-74. [CrossRef]

246. D'Arrigo, A.; Belluco, C.; Ambrosi, A.; Digito, M.; Esposito, G.; Bertola, A.; Fabris, M.; Nofrate, V.; Mammano, E.; Leon, A.; et al. Metastatic transcriptional pattern revealed by gene expression profiling in primary colorectal carcinoma. Int. J. Cancer 2005, 115, 256-262. [CrossRef]

247. Ki, D.H.; Jeung, H.C.; Park, C.H.; Kang, S.H.; Lee, G.Y.; Lee, W.S.; Kim, N.K.; Chung, H.C.; Rha, S.Y. Whole genome analysis for liver metastasis gene signatures in colorectal cancer. Int. J. Cancer 2007, 121, 2005-2012. [CrossRef]

248. Nadal, C.; Maurel, J.; Gascon, P. Is there a genetic signature for liver metastasis in colorectal cancer? World J. Gastroenterol. 2007, 13, 5832-5844. [CrossRef]

249. Li, M.; Lin, Y.M.; Hasegawa, S.; Shimokawa, T.; Murata, K.; Kameyama, M.; Ishikawa, O.; Katagiri, T.; Tsunoda, T.; Nakamura, Y.; et al. Genes associated with liver metastasis of colon cancer, identified by genome-wide cDNA microarray. Int. J. Oncol. 2004, 24, 305-312. [CrossRef]

250. Lim, B.; Mun, J.; Kim, J.H.; Kim, C.W.; Roh, S.A.; Cho, D.H.; Kim, Y.S.; Kim, S.Y.; Kim, J.C. Genome-wide mutation profiles of colorectal tumors and associated liver metastases at the exome and transcriptome levels. Oncotarget 2015, 6, 22179-22190. [CrossRef] 
251. Goryca, K.; Kulecka, M.; Paziewska, A.; Dabrowska, M.; Grzelak, M.; Skrzypczak, M.; Ginalski, K.; Mroz, A.; Rutkowski, A.; Paczkowska, K.; et al. Exome scale map of genetic alterations promoting metastasis in colorectal cancer. BMC Genet. 2018, 19, 85. [CrossRef]

252. Li, C.; Shen, Z.; Zhou, Y.; Yu, W. Independent prognostic genes and mechanism investigation for colon cancer. Biol. Res. 2018, 51, 10. [CrossRef] [PubMed]

253. Dong, Z.; Wang, X.; Evers, B.M. Site-specific DNA methylation contributes to neurotensin/neuromedin N expression in colon cancers. Am. J. Physiol. Gastrointest. Liver Physiol. 2000, 279, G1139-G1147. [CrossRef] [PubMed]

254. Mori, Y.; Olaru, A.V.; Cheng, Y.; Agarwal, R.; Yang, J.; Luvsanjav, D.; Yu, W.; Selaru, F.M.; Hutfless, S.; Lazarev, M.; et al. Novel candidate colorectal cancer biomarkers identified by methylation microarray-based scanning. Endocr. Relat. Cancer 2011, 18, 465-478. [CrossRef] [PubMed]

255. Roperch, J.P.; Incitti, R.; Forbin, S.; Bard, F.; Mansour, H.; Mesli, F.; Baumgaertner, I.; Brunetti, F.; Sobhani, I. Aberrant methylation of NPY, PENK, and WIF1 as a promising marker for blood-based diagnosis of colorectal cancer. BMC Cancer 2013, 13, 566. [CrossRef]

256. Mitchell, S.M.; Ross, J.P.; Drew, H.R.; Ho, T.; Brown, G.S.; Saunders, N.F.; Duesing, K.R.; Buckley, M.J.; Dunne, R.; Beetson, I.; et al. A panel of genes methylated with high frequency in colorectal cancer. BMC Cancer 2014, 14, 54. [CrossRef]

257. Kamimae, S.; Yamamoto, E.; Kai, M.; Niinuma, T.; Yamano, H.O.; Nojima, M.; Yoshikawa, K.; Kimura, T.; Takagi, R.; Harada, E.; et al. Epigenetic silencing of NTSR1 is associated with lateral and noninvasive growth of colorectal tumors. Oncotarget 2015, 6, 29975-29990. [CrossRef]

258. Li, J.; Chen, C.; Bi, X.; Zhou, C.; Huang, T.; Ni, C.; Yang, P.; Chen, S.; Ye, M.; Duan, S. DNA methylation of CMTM3, SSTR2, and MDFI genes in colorectal cancer. Gene 2017, 630, 1-7. [CrossRef]

259. Ma, Z.; Williams, M.; Cheng, Y.Y.; Leung, W.K. Roles of methylated DNA biomarkers in patients with colorectal cancer. Dis. Markers 2019, 2019, 2673543. [CrossRef]

260. Suzuki, H.; Yamamoto, E.; Yamano, H.O.; Nakase, H.; Sugai, T. Integrated analysis of the endoscopic, pathological and molecular characteristics of colorectal tumorigenesis. Digestion 2019, 99, 33-38. [CrossRef]

261. Tham, C.; Chew, M.; Soong, R.; Lim, J.; Ang, M.; Tang, C.; Zhao, Y.; Ong, S.Y.; Liu, Y. Postoperative serum methylation levels of TAC1 and SEPT9 are independent predictors of recurrence and survival of patients with colorectal cancer. Cancer 2014, 120, 3131-3141. [CrossRef]

262. Bian, Q.; Chen, J.; Qiu, W.; Peng, C.; Song, M.; Sun, X.; Liu, Y.; Ding, F.; Chen, J.; Zhang, L. Four targeted genes for predicting the prognosis of colorectal cancer: A bioinformatics analysis case. Oncol. Lett. 2019, 18, 5043-5054. [CrossRef] [PubMed]

263. Zhao, Z.W.; Fan, X.X.; Yang, L.L.; Song, J.J.; Fang, S.J.; Tu, J.F.; Chen, M.J.; Zheng, L.Y.; Wu, F.Z.; Zhang, D.K.; et al. The identification of a common different gene expression signature in patients with colorectal cancer. Math. Biosci. Eng. 2019, 16, 2942-2958. [CrossRef] [PubMed]

264. Gao, X.; Yang, J. Identification of Genes related to clinicopathological characteristics and prognosis of patients with colorectal cancer. DNA Cell Biol. 2020, 39, 690-699. [CrossRef] [PubMed]

265. Mori, Y.; Cai, K.; Cheng, Y.; Wang, S.; Paun, B.; Hamilton, J.P.; Jin, Z.; Sato, F.; Berki, A.T.; Kan, T.; et al. A genome-wide search identifies epigenetic silencing of somatostatin, tachykinin-1, and 5 other genes in colon cancer. Gastroenterology 2006, 131, 797-808. [CrossRef]

266. Liu, Y.; Chew, M.H.; Tham, C.K.; Tang, C.L.; Ong, S.Y.; Zhao, Y. Methylation of serum SST gene is an independent prognostic marker in colorectal cancer. Am. J. Cancer Res. 2016, 6, 2098-2108.

267. Kobayashi, M.; Matsubara, N.; Nakachi, Y.; Okazaki, Y.; Uchino, M.; Ikeuchi, H.; Song, J.; Kimura, K.; Yasuhara, M.; Babaya, A.; et al. Hypermethylation of corticotropin releasing hormone receptor-2 gene in ulcerative colitis associated colorectal cancer. In Vivo 2020, 34, 57-63. [CrossRef]

268. Smith, A.M.; Justin, T.; Michaeli, D.; Watson, S.A. Phase I/II study of G17-DT, an anti-gastrin immunogen, in advanced colorectal cancer. Clin. Cancer Res. 2000, 6, 4719-4724.

269. Falciani, C.; Lelli, B.; Brunetti, J.; Pileri, S.; Cappelli, A.; Pini, A.; Pagliuca, C.; Ravenni, N.; Bencini, L.; Menichetti, S.; et al. Modular branched neurotensin peptides for tumor target tracing and receptor-mediated therapy: A proof-of-concept. Curr. Cancer Drug Targets 2010, 10, 695-704. [CrossRef]

270. Falciani, C.; Accardo, A.; Brunetti, J.; Tesauro, D.; Lelli, B.; Pini, A.; Bracci, L.; Morelli, G. Target-selective drug delivery through liposomes labeled with oligobranched neurotensin peptides. ChemMedChem. 2011, 6, 678-685. [CrossRef] 
271. Schulz, J.; Rohracker, M.; Stiebler, M.; Goldschmidt, J.; Stöber, F.; Noriega, M.; Pethe, A.; Lukas, M.; Osterkamp, F.; Reineke, U.; et al. Proof of therapeutic efficacy of a ${ }^{177} \mathrm{Lu}$-labeled neurotensin receptor 1 antagonist in a colon carcinoma xenograft model. J. Nucl. Med. 2017, 58, 936-941. [CrossRef]

272. Levy, A.; Gal, R.; Granoth, R.; Dreznik, Z.; Fridkin, M.; Gozes, I. In vitro and in vivo treatment of colon cancer by VIP antagonists. Regul. Pept. 2002, 109, 127-133. [CrossRef]

273. Rick, F.G.; Buchholz, S.; Schally, A.V.; Szalontay, L.; Krishan, A.; Datz, C.; Stadlmayr, A.; Aigner, E.; Perez, R.; Seitz, S.; et al. Combination of gastrin-releasing peptide antagonist with cytotoxic agents produces synergistic inhibition of growth of human experimental colon cancers. Cell Cycle 2012, 11, 2518-2525. [CrossRef] [PubMed]

274. Koh, S.L.; Ager, E.; Malcontenti-Wilson, C.; Muralidharan, V.; Christophi, C. Blockade of the renin-angiotensin system improves the early stages of liver regeneration and liver function. J. Surg. Res. 2013, 179, 66-71. [CrossRef] [PubMed]

275. Takahashi, H.; Berber, E. Role of thermal ablation in the management of colorectal liver metastasis. Hepatobiliary Surg. Nutr. 2020, 9, 49-58. [CrossRef] [PubMed]

276. Mearadji, A.; Breeman, W.; Hofland, L.; van Koetsveld, P.; Marquet, R.; Jeekel, J.; Krenning, E.; van Eijck, C. Somatostatin receptor gene therapy combined with targeted therapy with radiolabeled octreotide: A new treatment for liver metastases. Ann. Surg. 2002, 236, 722. [CrossRef] [PubMed]

277. El-Salhy, M.; Dennerqvist, V. Effects of triple therapy with octreotide, galanin and serotonin on liver metastasis of human colon cancer in xenografts. Oncol. Rep. 2004, 11, 1177-1182. [CrossRef]

278. Ager, E.I.; Wen, S.W.; Chan, J.; Chong, W.W.; Neo, J.H.; Christophi, C. Altered efficacy of AT1R-targeted treatment after spontaneous cancer cell-AT1R upregulation. BMC Cancer 2011, 11, 274. [CrossRef]

279. Luo, Y.; Ohmori, H.; Shimomoto, T.; Fujii, K.; Sasahira, T.; Chihara, Y.; Kuniyasu, H. Anti-angiotensin and hypoglycemic treatments suppress liver metastasis of colon cancer cells. Pathobiology 2011, 78, 285-290. [CrossRef]

280. Jensen, L.H.; Olesen, R.; Petersen, L.N.; Boysen, A.K.; Andersen, R.F.; Lindebjerg, J.; Nottelmann, L.; Thomsen, C.E.B.; Havelund, B.M.; Jakobsen, A.; et al. NPY gene methylation as a universal, longitudinal plasma marker for evaluating the clinical benefit from last-line treatment with regorafenib in metastatic colorectal cancer. Cancers 2019, 11, 1649. [CrossRef]

281. Song, Y.; Xu, Y.; Wang, Z.; Chen, Y.; Yue, Z.; Gao, P.; Xing, C.; Xu, H. MicroRNA-148b suppresses cell growth by targeting cholecystokinin-2 receptor in colorectal cancer. Int. J. Cancer 2012, 131, 1042-1051. [CrossRef]

282. Sarkar, C.; Chakroborty, D.; Chowdhury, U.R.; Dasgupta, P.S.; Basu, S. Dopamine increases the efficacy of anticancer drugs in breast and colon cancer preclinical models. Clin. Cancer Res. 2008, 14, 2502-2510. [CrossRef] [PubMed]

283. Wang, X.; Wang, N.; Yang, Y.; Wang, X.; Liang, J.; Tian, X.; Zhang, H.; Leng, X. Polydopamine nanoparticles carrying tumor cell lysate as a potential vaccine for colorectal cancer immunotherapy. Biomater. Sci. 2019, 7, 3062-3075. [CrossRef] [PubMed]

284. Gao, S.; Song, J.; Chen, F.; Wang, Q.; Liu, X.; Ren, H.; Li, Y.; Meng, X.; Zhou, Y.; Lu, S.; et al. A novel immunotoxin-rCCK8PE38 targeting of CCK-R overexpressed colon cancers. J. Drug Target 2015, 23, 462-468. [CrossRef] [PubMed]

(C) 2020 by the authors. Licensee MDPI, Basel, Switzerland. This article is an open access article distributed under the terms and conditions of the Creative Commons Attribution (CC BY) license (http://creativecommons.org/licenses/by/4.0/). 